\title{
Myxomycetes of boreal forests of the Laplandskiy State Nature Biosphere Reserve (Kola Peninsula, Russia)
}

\section{Yuri K. Novozhilov', Oleg N. Shchepin', Vladimir I. Gmoshinskiy², Martin Schnittler ${ }^{3}$}

1 Komarov Botanical Institute of the Russian Academy of Sciences, Laboratory of Systematics and

Geography of Fungi, Prof. Popov Street 2, 197376 St. Petersburg, Russia

2 Lomonosov Moscow State University,

Faculty of Biology, Mycology and Algology Dept.,

119234 Moscow, Russia

3 Institute of Botany and Landscape Ecology,

Greifswald University,

Soldmannstr. 15, D-17489 Greifswald, Germany

* Corresponding author:

yurinovozhilov@gmail.com

Keywords: Amoebozoa, Arctic, Kola Peninsula,

Myxogastria, Russia, biodiversity, mountainous tundra, northern taiga, slime molds, species inventory.

Article info:

Received: 01 July 2020

Accepted: 21 September 2020

Published online: 22 November 2020

Corresponding Editor: Nikki Heherson A. Dagamac

\section{Abstract}

Northern taiga forests and subalpine plant communities of the Laplandskiy State Nature Biosphere Reserve (Kola Peninsula, Russia) were surveyed for myxomycetes. A total of 1675 specimens of myxomycete fruit bodies (sporocarps) were registered, among them 1584 records from field collections and 92 obtained from 210 moist chamber cultures of ground litter, bark of living trees, wood, and weathered dung of moose and willow ptarmigan. Most of 125 taxa (124 morphospecies and one variety) representing 34 genera were recorded only in the field (104 taxa from 32 genera), but some were exclusively obtained from moist chamber cultures (8 taxa from 5 genera). All of the recorded species are new for the Laplandskiy Reserve. Species numbers decreased among the four studied forest associations along the elevation and mositure gradient, and the Shannon index showed a similar trend: spruce forest (PICa; 84 taxa, $H^{\prime}=3.8$ ), spruce-peat moss forest (PICb; 70, 3.5), dry spruce-pine forest (PIN; 62, 3.7), subalpine birch forest (SB; 30, 2.7). The estimated completeness of the survey according to the Chaol estimator was $66 \%$, indicating that most of the more common spe- 
cies should have been recovered. The trend among forest associations runs mainly parallel to diversity: PICa and PICb 83\%, PIN 47\%, SB 57\%. The myxomycete assemblage of dry coniferous forests is the most distinctive among the three forest types and shows the highest number of indicator species. The overall degree of specialization of myxomycetes is higher for substrate type than for forest associations. Among substrate types, species diversity and richness increase from litter over bark to wood.

\section{Introduction}

Taiga, or boreal forest, is the biggest biome in Russia. In the European part of Russia, the southern and middle subzones of this biome are rather well surveyed for myxomycetes (Novozhilov 1980, 1999, Schnittler \& Novozhilov 1996, Novozhilov \& Lebedev 2006, Barsukova et al. 2012, Erastova \& Novozhilov 2015, Gmoshinskiy \& Matveev 2016, Gmoshinskiy et al. 2019). However, the myxomycetes of the northern border of this biome, including mountain subalpine birch forests, remained poorly studied (Stephenson et al. 2000).

A number of studies are published for Finland and Norway, where taiga forests show a similar structure and species composition (Karsten 1882, Hintikka 1919, Härkönen 1979, Johannesen 1984b, Johannesen 1984a, Elvebakk et al. 1996, Härkönen et al. 1999, Härkönen \& Varis 2013, Johannesen \& Vetlesen 2020). In contrast, only four local species inventories have been carried out in the Kola Peninsula and adjacent territories (Schnittler \& Novozhilov 1996, Novozhilov \& Schnittler 1997, Novozhilov et al. 1998, Erastova et al. 2017).

To fill this gap, we have conducted a quantitative survey that allowed to compile the first annotated checklist of myxomycete species of the Laplandskiy State Nature Biosphere Reserve (western Kola Peninsula). An effort was made to record or collect every myxomycete colony of sporocarps and to obtain samples of different substrate types for moist chamber cultures.

The primary objectives of this study were (1) to obtain baseline data on myxomycete abundance and biodiversity of the northern taiga forests, (2) to estimate the degree of completeness that can be achieved in this type of survey, and (3) to determine to which extent myxomycete assemblages vary between different vegetation types and substrates within the studied area.

\section{Materials and methods}

\author{
Study area
}

The Laplandskiy Reserve is located in the western part of the Kola Peninsula about $120 \mathrm{~km}$ south of Murmansk, between $67^{\circ} 10^{\prime}-68^{\circ} 05^{\prime} \mathrm{N}$ and $31^{\circ} 45^{\prime}-$ $32^{\circ} 45^{\prime} \mathrm{E}$, covering the major portion of the Chunatundra and the Salnye Tundry Mountains (Fig. 1). The reserve encompasses $2,784 \mathrm{~km}^{2}$. Its territory belongs entirely to the northern taiga zone (Ogureeva 2010). The border of the orohemiarctic zone runs 70-90 km apart from the reserve's northern border (Ahti et al. 1968). The southern border is 120-130 $\mathrm{km}$ north of the Arctic Circle. The main mountain range of the reserve, the Chunatundra, stretches from west to east for $40 \mathrm{~km}$. The southern foothill of the massif is enclosed by an arched tectonic depression filled with Chunozero lake, which reaches up to $40 \mathrm{~m}$ depth. The northernmost and highest peak, Ebruchorr, reaches $1115 \mathrm{~m}$ a.s.l. The climate of the Laplandskiy Reserve is rather humid, but as well continental, with long cold winters and short cool summers (Dfc in Köppen climate classification), which is typical for the Russian taiga ecoregion (Kottek et al. 2006; Hogan 2012).

Average monthly temperatures vary from $-13.5^{\circ} \mathrm{C}$ in February to $13.5{ }^{\circ} \mathrm{C}$ in July. The average annual precipitation is about $450 \mathrm{~mm}$, with ca. $40 \%$ falling as snow. The snow cover usually lasts from mid-October until end of May. Its distribution and the time of its melting in the mountains depend on the relief and slope exposition. Precipitation is lowest towards the end of the winter (from February to April, about $30 \mathrm{~mm}$ per month), the maximum is in August and September (Koroleva 1999; Marshall et al. 2016; Barkan 2020).

The mountain slopes are covered with northern 


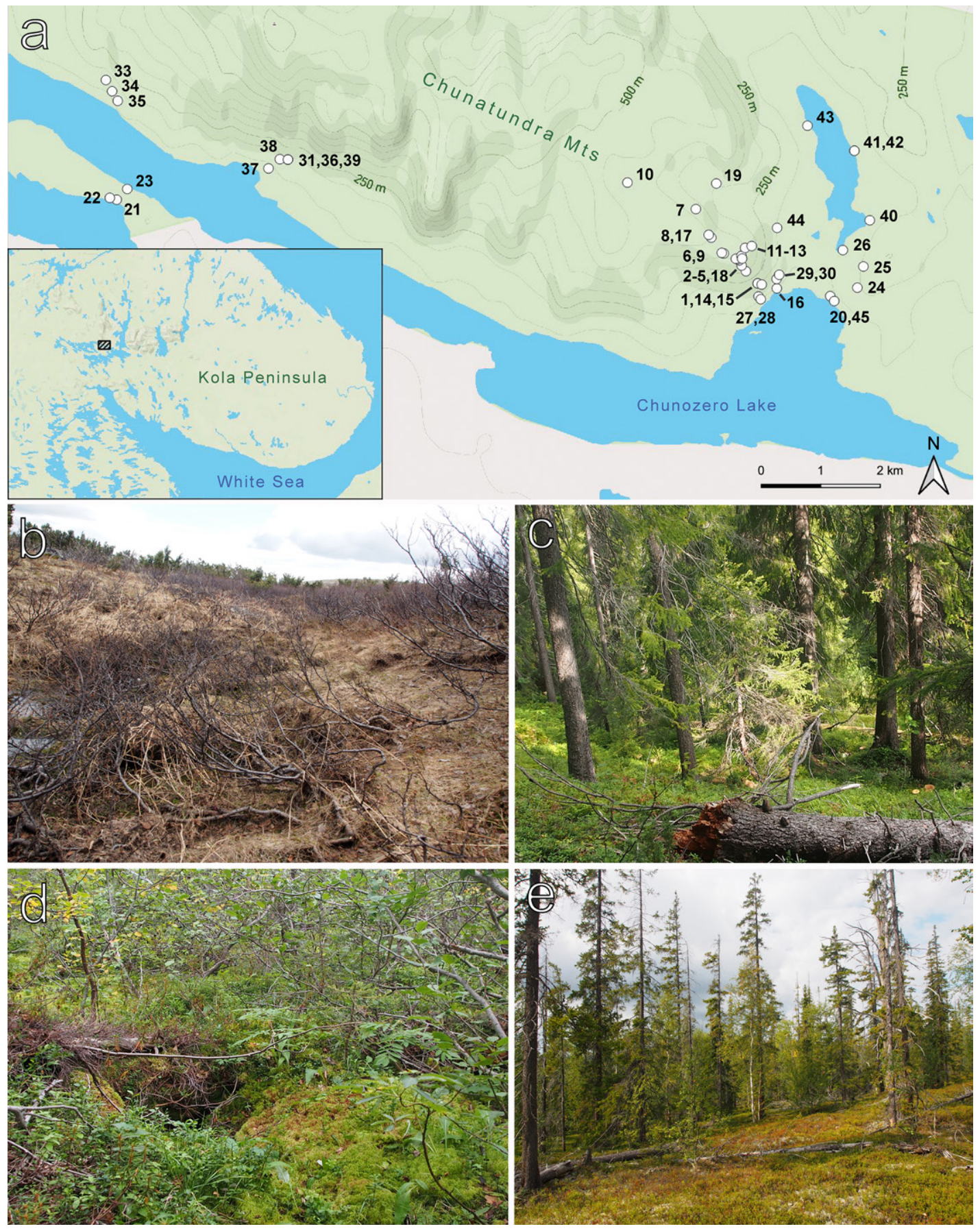

Fig. 1. Maps of the study area and images of typical habitats. a: schematic map of the study area, inset: geographical position of the Laplandskiy State Nature Biosphere Reserve within the Kola Peninsula, numbers and circles indicate the 44 sampled localities, b: subalpine birch forest (SB), c: spruce forest (PICa), d: understory layer in spruce-peat moss forest (PICb), e: dry spruce-pine forest (PIN). Map sources: Mapbox online service, localities indicated via QGIS. 
taiga forest, featuring spruce, pine and birch as the dominating tree species. The elevational timberline is already reached at ca. $380 \mathrm{~m}$ a.s.l.; it decreases near lakes but increases in sheltered valleys. The rounded gneiss peaks with average heights of 500-800 $\mathrm{m}$ a.s.l. are covered by arctic mountain tundra, consisting of heathlands dominated by dwarf shrubs and lichens. Snow-bed plant communities are most common in the middle oroarctic zone, at about $600 \pm 80$ $\mathrm{m}$ a.s.l., and are represented by moss cushions and grass fields which occupy a fairly narrow area near long-lasting snow patches (Koroleva 1999).

\section{Localities and vegetation types:}

The Laplandskiy State Nature Biosphere Reserve was exhaustively surveyed during three expeditions (three weeks in June 2015, three weeks in August 2015, and one week in July 2016).

This study was carried out along the slopes of the Chunatundra mountain range near lake Chunozero (Fig. 1a), focusing mainly on the northern taiga forest (dominated by spruce) and the subalpine birch forest (SB). The myxomycetes in the mountain tundra were not specifically studied because they had been thoroughly investigated in the adjacent Khibiny Mountains, situated only $45 \mathrm{~km}$ east from the reserve (Schnittler \& Novozhilov 1996, Erastova et al. 2017).

The following brief description refers to vegetation types named and classified by Ahti et al. (1968). Names of vascular plants are listed according to Czerepanov (1995). Each studied locality was assigned to one of the vegetation types. Numbers of the studied localities are shown in Fig. 1a. Geographical data and vegetation types of all studied localities are given below.

\section{Northern taiga spruce forests}

Spruce forests mainly with Picea obovata Ledeb. with well-developed undergrowth of Prunus padus L. and Sorbus aucuparia L. are most common in the reserve between 150-250 $\mathrm{m}$ a.s.l. Some of these forests are heavily damaged by fires around the Salnye Tundry mountains and greatly affected by airborne chemical pollution and fires in the surroundings of the Chunatundra mountains (Lukina \& Chernen'kova 2008).
The most common type of soil is podzol, if the soil is not waterlogged. Its upper layer is acidic due to falling needles, favoring lichens and some mosses as pioneer plants, which are on favorable sites replaced by dwarf shrubs like Vaccinium myrtillus L. and V. vitis-idaea L. The moss layer is well developed: Pleurozium schreberi (Brid.) Mitt., Hylocomium splendens (Hedw.) Schimp., and Dicranum spp. dominate drier sites; in wet depressions Sphagnum spp. prevails (Lukina \& Chernen'kova 2008).

In pure spruce forests trees may reach $80 \mathrm{~cm}$ in diameter and form a closed canopy, therefore litter and logs are shaded and dry out slowly. These habitats are rich in coarse woody debris at different stages of decomposition. There are windfallen trees (uprooted together with the surrounding soil) and uneven-aged "regeneration gaps" in the birch and spruce forest canopy (Lukina \& Chernen'kova 2008). The fallen trees are mainly shaded and wet, so decay proceeds faster than in the drier spruce forest mixed with pine. The stock of the litter (mainly dead mosses and needles) under tree crowns reaches 40 t/ha (Lukina \& Chernen'kova 2008).

Within these spruce forests, three associations can be differentiated according to the combination of dominant dwarf shrub species, lichens and mosses. We surveyed myxomycetes in moderately dry spruce forest (ground layer dominated by bryophytes), moist spruce-peat moss forest (ground layer dominated by Sphagnum spp.), and in very dry, open spruce-pine forest (ground layer with lichens, bryophytes, and dwarf Ericaceae shrubs).

SPRUCE FOREST (PICa) - localities 14-16, 20, 25, 34, 35, 36, 37, 38, 39, 44, 45 (Fig. 1c).

In this association, spruce is at its optimum: the tallest trees can reach $50-80 \mathrm{~cm}$ diameter at breast height (DBH). The understory layer is fragmented but sometimes well-developed, with trees of Prunus padus L., Sorbus aucuparia L. and a rich herb layer, dominated by dwarf shrubs and herbs, such as Vaccinium spp., Empetrum nigrum L., Geranium sylvaticum $\mathrm{L}$., and Cornus suecica $\mathrm{L}$. It is rich in mosses of the genus Dicranum, and ferns in habitats with sufficient spring-water moisture.

Reserve station "Nizhnaja Chuna", ecological route El'njun-2. LOC. 14: SE slope, $292 \pm 10 \mathrm{~m}$ a.s.l., $67^{\circ} 39^{\prime} 11.2^{\prime \prime} \mathrm{N} 32^{\circ} 37^{\prime} 20.1^{\prime \prime E}$; LOC. 15: SE slope, $302 \pm 10$ 
m a.s.l., $67^{\circ} 39^{\prime} 10.6^{\prime \prime} \mathrm{N} 32^{\circ} 37^{\prime} 25.8^{\prime \prime} \mathrm{E}$; LOC. 16: SE slope, $259 \pm 10 \mathrm{~m}$ a.s.l., $67^{\circ} 39^{\prime} 08.5^{\prime \prime} \mathrm{N} 32^{\circ} 37^{\prime} 47.3^{\prime \prime E}$; LOC. 20 : S slope, $111 \pm 10 \mathrm{~m}$ a.s.l., $67^{\circ} 39^{\prime} 04.3^{\prime \prime} \mathrm{N} 32^{\circ} 39^{\prime} 03.3^{\prime \prime E}$; LOC. 25: S slope, $232 \pm 10 \mathrm{~m}$ a.s.l., $67^{\circ} 39^{\prime} 20.4^{\prime \prime} \mathrm{N}$ $32^{\circ} 39^{\prime} 50.5$ "E; LOC. 44: S slope, $227 \pm 10 \mathrm{~m}$ a.s.l., $67^{\circ} 39^{\prime} 41.4^{\prime \prime} \mathrm{N} 32^{\circ} 37^{\prime} 47.7^{\prime \prime E}$; LOC. 45: S slope, $167 \pm 10$ $\mathrm{m}$ a.s.l., 67 39'01.6"N 32 39'09.0"E; brook "Ruchei Kupletskogo", southern shore of lake Chunozero. LOC. 34: W slope, $169 \pm 10 \mathrm{~m}$ a.s.l., $67^{\circ} 40^{\prime} 55.6^{\prime \prime} \mathrm{N}$ $32^{\circ} 22^{\prime} 01.3 " \mathrm{E}$; LOC. 35: $\mathrm{W}$ slope, $162 \pm 10 \mathrm{~m}$ a.s.l., 67 $40^{\prime} 50.4^{\prime \prime} \mathrm{N} 32^{\circ} 22^{\prime} 09.3$ "E; LOC. 36: SW slope, $176 \pm 10$ $\mathrm{m}$ a.s.l., $67^{\circ} 40^{\prime} 18.5^{\prime \prime} \mathrm{N} 32^{\circ} 26^{\prime} 11.5^{\prime \prime} \mathrm{E}$; near Seidapakhta Mt., southern shore of lake Chunozero. LOC. 37: SW slope, $134 \pm 10 \mathrm{~m}$ a.s.l., $67^{\circ} 40^{\prime} 13.7^{\prime \prime} \mathrm{N} 32^{\circ} 25^{\prime} 43.9^{\prime \prime} \mathrm{E}$; LOC. 38: SW slope, $174 \pm 10 \mathrm{~m}$ a.s.l., $67^{\circ} 40^{\prime} 18.7^{\prime \prime} \mathrm{N}$ $32^{\circ} 26^{\prime} 00.0^{\prime \prime E}$; LOC. 39: SW slope, $176 \pm 10 \mathrm{~m}$ a.s.l., $67^{\circ} 40^{\prime} 18.5^{\prime \prime} \mathrm{N} 32^{\circ} 26^{\prime} 11.5^{\prime \prime} \mathrm{E}$.

SPRUCE-PEAT MOSS FOREST (PICb) - localities 19, 26-31, 33, 40-43 (Fig. 1d). This spruce forest type occurs at the foot of slopes and near rivulets where the Sphagnum species constitute a nearly continuous vegetation carpet.

Reserve station "Nizhn'aja Chuna", ecological route El'njun-2. LOC. 19: S slope, $368 \pm 10 \mathrm{~m}$ a.s.l., $67^{\circ} 40^{\prime} 05.5^{\prime \prime} \mathrm{N} 32^{\circ} 36^{\prime} 21.2^{\prime \prime E}$; LOC. 26: W slope, $167 \pm 10$ $\mathrm{m}$ a.s.l., $67^{\circ} 39^{\prime} 29.3^{\prime \prime} \mathrm{N} 32^{\circ} 39^{\prime} 21.3^{\prime \prime E}$; LOC. 27: W slope, $138 \pm 10 \mathrm{~m}$ a.s.l., $67^{\circ} 39^{\prime} 04.1^{\prime \prime} \mathrm{N} 32^{\circ} 37^{\prime} 21.3^{\prime \prime E}$; LOC. 28: S slope, $145 \pm 10 \mathrm{~m}$ a.s.l., $67^{\circ} 39^{\prime} 02.6^{\prime \prime} \mathrm{N} 32^{\circ} 37^{\prime} 24.4^{\prime \prime}$; LOC. 29: $\mathrm{S}$ slope, $145 \pm 10 \mathrm{~m}$ a.s.l., $67^{\circ} 39^{\prime} 02.6^{\prime \prime} \mathrm{N}$ $32^{\circ} 37^{\prime} 47.0^{\prime \prime E}$; LOC. 30: S slope, $140 \pm 10 \mathrm{~m}$ a.s.l., $67^{\circ} 39^{\prime} 15.9^{\prime \prime} \mathrm{N} 32^{\circ} 37^{\prime} 50.7^{\prime \prime E}$; near Seidapakhta Mt., southern shore of lake Chunozero. LOC. 31: SW slope,

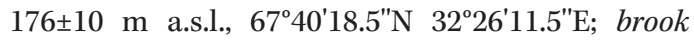
"Ruchei Kupletskogo", near the waterfall. LOC. 33: W slope, $191 \pm 10 \mathrm{~m}$ a.s.l., $67^{\circ} 41^{\prime} 01.7^{\prime \prime} \mathrm{N} 32^{\circ} 21^{\prime} 52.5^{\prime \prime} \mathrm{E}$; eastern shore of lake El'javr. LOC. 40: W slope, $153 \pm 10 \mathrm{~m}$ a.s.l., $67^{\circ} 39^{\prime} 45.5^{\prime \prime} \mathrm{N} 32^{\circ} 39^{\prime} 59.6^{\prime \prime} \mathrm{E}$; LOC. 41 : W slope, $154 \pm 10 \mathrm{~m}$ a.s.l., $67^{\circ} 40^{\prime} 23.3^{\prime \prime} \mathrm{N} 32^{\circ} 39^{\prime} 37.7^{\prime \prime} \mathrm{E}$; LOC. 42: W slope, $164 \pm 10 \mathrm{~m}$ a.s.l., $67^{\circ} 40^{\prime} 23.5^{\prime \prime} \mathrm{N}$ $32^{\circ} 39^{\prime} 37.9^{\prime \prime E}$; LOC. 43: E slope, $222 \pm 10$ m a.s.l., $67^{\circ} 40^{\prime} 36.9^{\prime \prime} \mathrm{N} 32^{\circ} 38^{\prime} 30.9^{\prime \prime} \mathrm{E}$.

DRY SPRUCE-PINE FOREST (PIN) - localities 2124 (Fig. 1e).

A dry, open forest with medium-sized, 30-40 cm DBH scattered trees of Picea obovata Ledeb. and Pinus sylvestris L. accompanied by many saplings of both species, together with Juniperus communis L., and Betula pubescens Ehrh. Due to the rather large distances between trees (5-20 $\mathrm{m}$ ) and their narrow, pyramid-shaped form, the canopy is not closed. This plant community is very rich in lichens (Cladonia mitis Sandst., C. rangiferina (L.) Weber ex Wigg., C. stellaris (Opiz) Pouzar \& Vezda). Mosses (Polytrichum piliferum Hedwig, Hylocomium splendens (Hedw.) Schimp., Dicranum fuscescens Turner, D. drummondii Müll. Hal.) and liverworts (Barbilophozia hatcheri (A. Evans) Loeske and Ptilidium ciliare (L.) Hampe) occur on hillslopes and terraces with good drainage (Neshataev \& Neshataeva 2002). The podzol soil is shallow and sandy. The water retention is low and the soil is moist only a short time after rainfalls. Many of the spruce and pine trees have been blown down by wind, so numerous fallen trees and branches lie on the soil. Spruce logs lie elevated on their branches for a long time and therefore the stems do not touch the ground directly. As a consequence, the decay of the stemwood is delayed, and the bark is much longer attached to the wood. Litter and logs are mostly exposed to sunlight and therefore dry out quickly after rain.

Cordon "Volok", southern shore of lake Saydalamina. LOC. 21: S slope, $104 \pm 10 \mathrm{~m}$ a.s.l., $67^{\circ} 39^{\prime} 56.7^{\prime \prime} \mathrm{N}$ $32^{\circ} 22^{\prime} 07.9^{\prime \prime E}$; LOC. 22: S slope, $104 \pm 10 \mathrm{~m}$ a.s.l., $67^{\circ} 39^{\prime} 57.7^{\prime \prime} \mathrm{N} 32^{\circ} 21^{\prime} 58.1^{\prime \prime E}$; LOC. 23: S slope, $35 \pm 10$ $\mathrm{m}$ a.s.l., $67^{\circ} 40^{\prime} 02.1^{\prime \prime} \mathrm{N} 32^{\circ} 22^{\prime} 22.9^{\prime \prime E}$. Reserve station "Nizhnaja Chuna". LOC. 24: S slope, $185 \pm 10$ m a.s.l., $67^{\circ} 39^{\prime} 08.9^{\prime \prime N} 32^{\circ} 39^{\prime} 41.9^{\prime \prime} \mathrm{E}$.

SUBALPINE BIRCH FOREST (SB) - localities 1-13, 17-18 (Fig. 1b).

This type of vegetation (Hämet-Ahti 1963, Wehberg et al. 2005) is common between 350 and $500 \mathrm{~m}$ a.s.l., mostly on S-exp. slopes sheltered from the prevailing cold winds from north and north-east, looking in some places like a forest tundra. It is a light forest with crooked Betula czerepanovii N.I. Orlova and a second species of rowan, Sorbus gorodkovii Pojark., forming a low canopy. Creeping individuals of spruce, aspen and rowan constitute a shrub layer together with willows, juniper, dwarf birch (Betula nana L.) and several species of Ericaceae (Empetrum hermaphroditum Lange ex Hagerup, Vaccinium uliginosum L., and Phyllodoce caerulea L. Bab.). Beside the lichens Cladonia spp. and Cetraria spp. prevail- 
ing at drier patches, the herb layer is represented by several ferns and a rather diverse community of flowering plants. On dry convex slopes, lichens, blueberries (Vaccinium myrtillus L.) or crowberries (Empetrum nigrum L.) prevail, whereas at moister sites cushions of Sphagnum spp. occur together with blueberries or crowberries. Along streams, birch is replaced by willow stands.

Reserve station "Nizhn'aja Chuna", ecological route El'njun-2. LOC. 1: SE slope, $317 \pm 10 \mathrm{~m}$ a.s.l., $67^{\circ} 39^{\prime} 17.8^{\prime \prime} \mathrm{N} 32^{\circ} 37^{\prime} 03.4^{\prime \prime E}$; LOC. 2: SE slope, 338 \pm 10 $\mathrm{m}$ a.s.l., $67^{\circ} 39^{\prime} 20.9^{\prime \prime} \mathrm{N} 32^{\circ} 36^{\prime} 57.2^{\prime \prime E}$; LOC. 3: SE slope, $363 \pm 10 \mathrm{~m}$ a.s.l., $67^{\circ} 39^{\prime} 23.7^{\prime \prime} \mathrm{N} 32^{\circ} 36^{\prime} 53.8^{\prime \prime E}$; LOC. 4: SE slope, $379 \pm 10 \mathrm{~m}$ a.s.l., $67^{\circ} 39^{\prime} 24.4^{\prime \prime} \mathrm{N} 32^{\circ} 36^{\prime} 51.7^{\prime \prime} \mathrm{E}$; LOC. 5: SE slope, $387 \pm 10 \mathrm{~m}$ a.s.l., $67^{\circ} 39^{\prime} 24.6^{\prime \prime} \mathrm{N}$ $32^{\circ} 36^{\prime} 49.0^{\prime \prime E}$; LOC.6: $\mathrm{S}$ slope, $404 \pm 10 \mathrm{~m}$ a.s.l., $67^{\circ} 39^{\prime} 27.5^{\prime \prime} \mathrm{N} 32^{\circ} 36^{\prime} 31.9^{\prime \prime E}$; LOC. 7 : N slope, $406 \pm 10$ $\mathrm{m}$ a.s.l., $67^{\circ} 39^{\prime} 51.6^{\prime \prime} \mathrm{N} 32^{\circ} 35^{\prime} 52.1 " \mathrm{E}$; LOC. 8: S slope, $437 \pm 10$ m a.s.l., $67^{\circ} 39^{\prime} 36.1^{\prime \prime N} 32^{\circ} 36^{\prime} 14.0^{\prime \prime E}$; LOC. 9: S slope, $402 \pm 10 \mathrm{~m}$ a.s.l., $67^{\circ} 39^{\prime} 27.8^{\prime \prime} \mathrm{N} 32^{\circ} 36^{\prime} 29.0^{\prime \prime} \mathrm{E} ; \mathbf{L O C}$. 10: $\mathrm{S}$ slope, $522 \pm 10 \mathrm{~m}$ a.s.l., $67^{\circ} 40^{\prime} 06.0^{\prime \prime} \mathrm{N} 32^{\circ} 34^{\prime} 14.7^{\prime \prime E}$; LOC. 11: E slope, $450 \pm 10 \mathrm{~m}$ a.s.l., $67^{\circ} 39^{\prime} 26.2^{\prime \prime} \mathrm{N}$ $32^{\circ} 36^{\prime} 57.0^{\prime \prime E}$; LOC. 12: E slope, $464 \pm 10 \mathrm{~m}$ a.s.l., $67^{\circ} 39^{\prime} 30.5^{\prime \prime} \mathrm{N} 32^{\circ} 37^{\prime} 02.2^{\prime E}$; LOC. 13: E slope, $442 \pm 10$ $\mathrm{m}$ a.s.l., $67^{\circ} 39^{\prime} 31.5^{\prime \prime} \mathrm{N} 32^{\circ} 37^{\prime} 11.5^{\prime \prime E}$; LOC. 17: N slope, $428 \pm 10 \mathrm{~m}$ a.s.l., $67^{\circ} 39^{\prime} 37.6^{\prime \prime} \mathrm{N} 32^{\circ} 36^{\prime} 10.4^{\prime \prime E}$; LOC. 18: SE slope, $362 \pm 10 \mathrm{~m}$ a.s.l., $67^{\circ} 39^{\prime} 24.7^{\prime \prime N} 32^{\circ} 36^{\prime} 57.9^{\prime \prime E}$.

\section{Specimen collection and substrate sampling}

For each forest type, an effort was made to examine all types of microhabitats upon which sporocarps of myxomycetes could potentially be found. Specimens were identified to the lowest possible taxonomic level according to Martin and Alexopoulos (1969) and various original descriptions from the literature (Farr 1976, Poulain et al. 2011), using a morphospecies concept. Myxomycete nomenclature follows Lado (2005-2020). Common and easily recognizable species were sometimes only recorded instead of being collected, whereas rare and not easily recognizable species were always preserved as herbarium specimens. The genus Ceratiomyxa was included in this study due to its ecological equivalence to the true myxomycetes. We defined a record (colony) as all sporocarps of one species that shared the same substrate and clustered together (thus likely to have developed from one plasmodium). For the purpose of making determinations, sporocarps were preserved as permanent slides in polyvinyl-lactophenol and/or glycerol gelatin, to distinguish between limeless and lime-containing structures.

Substrate samples were collected randomly within predefined plots of homogenous habitat structure, covering about $500 \mathrm{~m}^{2}$ and placed within two forest types (PICa: localities 15, 16; SB: localities 1, 4). For all plots, geographical coordinates were obtained with a hand-held GPS device and the WGS 84 coordinate system. A total of 321 substrate samples were collected for moist chamber cultures (Database S1). All myxomycete substrates were classified as following: " $l$ " for forest ground litter, " $b$ " for bark of living trees, "w" for woody debris, "d" for weathered dung of moose (Alces alces L.) and willow ptarmigan (Lagopus lagopus L.). Moist chamber cultures were set up in Petri dishes of $9 \mathrm{~cm}$ diam., with substrate pieces placed on a layer of filter paper. After $24 \mathrm{~h}$, the $\mathrm{pH}$ of the waterlogged substrates was measured using a pH meter Hanna HI98128. Cultures were incubated under ambient light and at room temperature $\left(20-24^{\circ} \mathrm{C}\right)$ for up to 90 days and examined for the presence of myxomycetes on six occasions (days 2-4, 6-8, 11-14, 20-22, 40-44 and 85-90) under high magnification with a dissecting microscope. A 'record' was defined herein as one or more fruiting bodies of a species that developed from a moist chamber culture.

\section{Data analysis}

To estimate completeness of the survey, the quantitative collection data (every fructification recorded) was used to construct an individual-based species accumulation curve with the program EstimateS (Gotelli \& Colwell 2011, Colwell 2014). Two diversity indices were calculated: Shannon's diversity index $\mathrm{H}^{\prime}=-\sum \mathrm{P}^{\mathrm{i}} \ln \mathrm{P}^{\mathrm{i}}$, where $\mathrm{P}^{\mathrm{i}}$ is the relative abundance (the proportion of the total number of individuals or records represented by the ith species) of a particular species (Magurran 2004), and the inverse Simpson's dominance index D $=1 / \sum \mathrm{P}^{\mathrm{i}} 2$. The mean number of species per genus $(\mathrm{S} / \mathrm{G})$ was used as an indicator of overall taxonomic diversity.

Myxomycete assemblages from different vegetation communities and substrates were com- 
pared by using the adjusted incidence-based Chao-Sørensen index $\left(\mathrm{C}_{\mathrm{cs}}\right)$. It was computed with EstimateS and used for a cluster analysis by the weighted pair-group method (WPGMA) with the program Statistica 10. Graphs were created with SigmaPlot 10.0. Species classified as rare (relative frequency $<0.5 \%$ of all records) were excluded from the abovementioned analysis (Chao et al. 2005, 2006). There are two sources of a bias in the sampling effort of the different plant associations studied: a) our efforts to collect sporocarps in the field were relatively similar in PICa (13 localities), PICb (12), and SB (15) but were smaller in PIN (4) due to the relative rarity of this association; b) the moist chamber culture technique was used only for PICa and SB (Table 1). Therefore, only field specimens were used in the comparative analysis of species diversity and species richness between the forest types, and data were rarified as described above.

To reveal the associations of the species with different types of substrates and plant communities, an indicator species analysis was performed (McCune \& Mefford 2006) using the 'multipatt' function from 'indicspecies' package in R with 'IndVal.g' as association function and 9999 permutations (De Cáceres \& Legendre 2009).

All microscopic measurements and observations were made under a light microscope Zeiss Axio Imager Al with differential interference contrast (DIC). Mean spore diameter was calculated from 10 spore measurements from each collection. Air-dried sporocarps were studied with a Zeiss motorized stereo microscope Discovery V20, and a JSM-6390 LA scanning electron microscope at $10-15 \mathrm{kV}$ at the Core Facility Center of the Komarov Botanical Institute of the Russian Academy of Sciences, St. Petersburg. For the latter, specimens were mounted on copper stubs using double-sided sticky film and sputter-coated with gold. Voucher specimens were deposited in the collection of the first author in the mycological herbarium of the Komarov Botanical Institute RAS, Laboratory of Systematics and Geography of Fungi (LE).

\section{Results and Discussion}

The following annotated checklist was compiled based on our quantitative survey. In the annotated species list, each taxon name is followed by abbreviations for names of myxomycete species (mentioned in Figs. 6, 7, Tables S1, S2, Supplementary Database S), and an abundance estimation in brackets, including the abundance class according to the ACOR scale (Stephenson 1993), and records from field / moist chamber cultures. Next, the occurrence of a species in the four different forest types and in the major substrate types is listed. The abbreviations are explained in the Materials and Methods. The next string preceded by the abbreviation "Loc." lists all localities where a species was found (see Figs. 1-2). Finally, all or some (indicated by the string “...”) specimen numbers are given referring to the herbarium LE. Nivicolous species recorded in the adjacent Khibiny Mountains (Novozhilov \& Schnittler 1997, Erastova et al. 2017) are labeled as « ${ }^{\mathrm{Khi}} »$.

\section{Annotated species list}

Arcyria affinis Rostaf. [ARCaff, O, 11/0] PICA: 4, PICB: 2, PIN: 5; W: 11; LOC. 14, 21, 27, 41; LE306177...

All specimens displayed a typical capillitium connected to the stalk apex and ornamented by warts, spines, cogs, half-rings and rings and with a number of ridges which may unite locally to form a reticulum.

Arcyria cinerea (Bull.) Pers. [ARCcin, C, 9/27] SB: 20, PICa: 12, PICb: 4; B: 13, L: 2, D: 9, W: 12; LOC. 1, 4, 14, 15, 16, 18, 30, 31, 35, 38, 42; LE306141...

All specimens found in the field show the typical morphology with long grey sporothecae. Specimens from moist chamber cultures with the bark of living trees or dung may have yellowish ovoid sporocarps and resemble A. pomiformis. The differentiation between these species was thoroughly described in Farr (1962) and Härkönen (1977b). Following these authors, we assigned to A. cinerea the specimens with a capillitium that shows two or three parts, including the part at base of sporotheca with smooth thick tubes, becoming thinner and ornamented by short spines in the middle part and by long spines in the upper part.

Arcyria ferruginea Saut. $\left[\mathrm{AR}^{\mathrm{Cf}} \mathrm{er}, \mathrm{R}, 4 / 0\right] \mathrm{PICa}$ : 2, PICb: 2; W: 4; LOC. 25, 38, 42; LE306225...

The capillitium of our specimens has characteristic features including a large brownish-orange capillitium connected to the stalk apex and orna- 
mented with warts and spirally arranged rings and half-rings and usually reticulate ridges. Spores pale ochraceous, large, 9-11 $\mu \mathrm{m}$ diam.

Arcyria helvetica (Meyl.) H. Neubert, Nowotny \& K. Baumann [ARChel, R, 2/0] PICa: 2; W: 2; LOC. 25, 39; LE306224, 306612.

Both specimens have the typical conspicuous peridium persisting partly as a wine-red, slightly iridescent, funnel-shaped calyculus comprising about one third of the sporotheca.

Arcyria incarnata (Pers. ex J.F. Gmel.) Pers. [ARCinc, C, 40/1] PICa: 22, PICb: 4, PIN: 15; W: 41; LOC. 14, 15, 20, 21, 22, 23, 33, 38, 39, 40, 43, 44; LE306035...

Arcyria minuta Buchet [ARCmin, R, 1/0] PIN: 1; W: 1; LOC. 21 ; LE306357.

Arcyria obvelata (Oeder) Onsberg [ARCobv, O, 24/0] PICa: 9, PICb: 12, PIN: 3; W: 24; LOC. 14, 20 , 21, 22, 25, 27, 30, 33, 35, 38, 41, 42, 43, 44; LE306090...

Arcyria oerstedii Rostaf. [ARCoer, R, 7/0] PICa: 4, PICb: 1, PIN: 2; W: 7; LOC. 14, 21, 23, 25, 30, 34; LE306360...

All specimens represent typical form, displaying numerous spines on the threads of the capillitium which easily detaches from the calyculus.

Arcyria pomiformis (Leers) Rostaf. [ARCpom, O, 23/2] PICa: 4, PICb: 2, PIN: 19; W: 25; LOC. 14, 15, 16, 21, 22, 23, 29, 33; LE306331... Fig. 2a.

This is one of the commonest lignicolous species in the dry spruce-pine forest of the reserve, forming minute sporocarps on pine and spruce, from large logs to small branches, if the surface is still solid and smooth with dense and relatively dry wood. It often occurs on burned wood as well. Our collections show the typical ovate to globose pale ochraceous sporangia and the capillitium marked with cogs, short spines or half rings.

Arcyria stipata (Schwein.) Lister [ARCsti, R, 1/0] PICb: 1, W: 1; LOC. 33; LE306556.

Only one specimen which shows the typical capillitium with bulb-like thickenings and numerous free ends. The tubules are $3-5 \mu \mathrm{m}$ diam., bearing $3-4$ spirals intermixed with spines, cogs, half-rings or occasional rings and reticulations. Spores are covered by small verrucae and large warts, $7-8 \mu \mathrm{m}$ diam.

Badhamia foliicola Lister [BADfol, R, 3/0] PICa: 3; W: 3; LOC. 20; LE 306072...

Barbeyella minutissima Meyl. [BARmin,
R, 8/0] PICa: 2, PICb: 6; W: 8; LOC. 20, 30, 34; LE306496..., Fig. 2b.

This species is common on the lower side of moss-covered, moderately to strongly decayed large logs of spruce lying on the ground in spruce-peat moss forest (Fig. 2). Distribution and ecology of this species were described in detail (Schnittler et al. 2000, Stephenson et al. 2019).

Calomyxa metallica (Berk.) Nieuwl. [CALmet, R, 3/0] PICa: 2, PICb: 1; W: 3; LOC. 14, 28; LE306147...

Ceratiomyxa fruticulosa (O.F.Mull.) T.Macbr. [CERfru, O, 14/0] PICa: 5, PICb: 5, PIN: 4; W: 14; LOC. 14, 20, 21, 23, 28, 30, 31; LE306294...

Clastoderma debaryanum A. Blytt [CLAdeb, R, 6/0] PICa: 1, PICb: 5; W: 6; LoC. 30, 39, 41; LE306496...

Collaria arcyrionema (Rostaf.) Nann.-Bremek. ex Lado [COLanm, O, 9/0] PICa: 4, PICb: 5; W: 9; LOC. 14, 20, 30, 43; LE 306094...

Colloderma oculatum (C. Lippert) G. Lister [CODocu, A, 66/0] PICa: 28, PICb: 32, PIN: 6; W: 66; LOC. 14, 21, 22, 23, 25, 29, 30, 35, 37, 38, 39, 40, 41, 43; LE306499..., Fig. 2c.

All specimens were found on decorticated wood with a slimy appearance, covered with algae and liverworts mostly in shady habitats or at the margins of bogs. All specimens possess small sporocarps $(0.3-0.5 \mathrm{~mm})$ with very iridescent, thin and translucent peridia (Fig. 2c). A columella was not found. The capillitium is almost colorless, arising from the base, forming a large-meshed net, the tubulae up to $1.5 \mu \mathrm{m}$ in diameter, smooth. The same minute, scattered fructifications were frequently observed in other regions of Fennoscandia, also on large wet coniferous logs (Eliasson 1981, Schnittler \& Novozhilov 1996, Härkönen \& Varis 2013).

This species occurred often with B. minutissima and Lepidoderma tigrinum, the species that are able to fruit on very thin slimy layers of liverworts, covered with a water film.

Comatricha elegans (Racib.) G. Lister [COMele, R, 7/0] PICa: 1, PICb: 1, PIN: 5; W: 7; LOC. 21, 34, 43; LE $306312 . .$.

Comatricha ellae Härk. [COMell, R, 4/0] PICa: 1, PIN: 3; W: 4; LOC. 21, 22, 38; LE 306353...

Comatricha laxa Rostaf. [COMlax, R, 3/0] PICa: 1, PIN: 2; W: 3; LOC. 21, 22, 34; LE306303...

Comatricha nigra (Pers. ex J.F. Gmel.) J. Schröt. 
[COMnig, C, 45/1] SB: 1, PICa: 10, PICb: 12, PIN: 23; B: 1 , W: 45; LOC. 1, 14, 19, 20, 21, 22, 23, 24, 29, 30, 33, 35, 37, 38, 40, 41, 42, 43; LE306327..., Fig. 2d.

This is one of the most common lignicolous species in the reserve. It prefers large coarse woody debris, occurring usually on dry wood in open spruce and pine-lichen forest. This ecological niche is as well occupied by $C$. elegans and $C$. ellae, but $C$. nigra differs from both species by larger size (1.5-2 mm height), longer stalk and an undeveloped surface capillitium net (Härkönen 1977a).

Cribraria argillacea (Pers. ex J.F. Gmel.) Pers. [CRIarg, O, 13/0] PICa: 5, PICb: 5, PIN: 3; W: 13; LoC. 14, 20, 21, 22, 23, 28, 30, 35, 44; LE306398...

As typical for the genus, this species grows preferably on strongly decayed wood of spruce.

Cribraria aurantiaca Schrad. [CRIaur, O, 10/1] SB: 1, PICa: 4, PICb: 3, PIN: 3; L: 1, W: 10; LoC. 1, 14, 21, 22, 33, 39, 41, 43; LE306444...

Cribraria cancellata (Batsch) Nann.-Bremek. [CRIcan, C, 37/0] PICa: 11, PICb: 11, PIN: 15; W: 37; LOC. 14, 21, 23, 30, 35, 36, 41, 43, 44; LE306302...

Cribraria intricata Schrad. [CRIint, R, 1/0] PIN: 1; W: 1; LOC. 21; LE307691.

Cribraria languescens Rex [CRIlan, R, 1/0] PICa: 1; W: 1; LOC. 14; LE306133.

Cribraria macrocarpa Schrad. [CRImac, R, 3/0] PICa: 1, PICb: 1, PIN: 1; W: 3; LOC. 14, 22, 43; LE306236..., Fig. 2e.

Only three specimens but with the typical large peridial cup with numerous dark ribs radiating upwards from the base of sporotheca, with many perforations in the upper part with dark nodes.

Cribraria microcarpa (Schrad.) Pers. [CRImac, O, 9/6] SB: 1, PICa: 4, PICb: 10; L: 1, W: 14; LOC. 1, 14, 15, 27, 30, 37, 38; LE306168..

Cribraria oregana H.C. Gilbert [CRIore, C, 44/2] PICa: 10, PICb: 19, PIN: 17; W: 46; LOC. 14, 15, 21, 22, 23, 24, 30, 33, 35, 37, 42, 43; LE306103...

Cribraria persoonii Nann.-Bremek. [CRIper, R, 8/0] PICa: 2, PICb: 3, PIN: 3; w: 8; LOC. 14, 23, 33, 37, 43; LE306154..

Cribraria piriformis Schrad. [CRIpir, O, 9/0] PICa: 2, PICb: 2, PIN: 5; W: 9; LOC. 14, 21, 22, 30, 33; LE306181...

Cribraria purpurea Schrad. [CRIpur, R, 3/0] PICa: 3; w: 3; LOC. 39; LE306609..., Fig. 2 f.

Cribraria rufa (Roth) Rostaf. [CRIruf, O, 12/0]
PICa: 4, PICb: 3, PIN: 5; W: 12; LOC. 14, 21, 23, 25, 27 , 33, 39, 43; LE306214..., Fig. 2g.

Our collections include bright orange-red sporocarps up to $2 \mathrm{~mm}$ height. The peridial cup is well-developed and comprises nearly half the sporotheca, the peridial net is wide-meshed, consisting of flattened orange threads with small flat nodes which are often imperceptible, calcic granules are pale and up to $2 \mu \mathrm{m}$ in diam.

Cribraria splendens (Schrad.) Pers. [CRIspl, O, 12/0] PICa: 8, PICb: 4; W: 12; LOC. 14, 33; LE306541...

Cribraria stellifera Nowotny \& H. Neubert [CRIste, R, 1/0] PICb: 1; W: 1; LOC. 29; LE306493.

This species, recorded as new for Russia, is represented by a small colony of long-stalked sporocarps. The peridial cup remains as a small basal disk only, but stretches over the larger part of the sporotheca as a regular peridial net with thickened nodes, which are connected with each other forming triangular to quadrangular meshes, the nodes rounded to elliptical, relatively large, densely adorned with calcic granules, appearing star-like due to many free-ending threads, which often repeatedly branch.

Cribraria tenella Schrad. [CRIten, R, 7/0] PICa: 4, PICb: 1, PIN: 2; W: 7; LOC. 14, 21, 24, 25, 30; LE306183...

Cribraria violacea Rex [CRIvio, R, 6/0] PICa: 6; W: 6; LOC. 20; LE306078...

Cribraria vulgaris Schrad. [CRIvul, R, 6/0] PICa: 4, PIN: 2; W: 6; LOC. 14, 21, 35; LE306156...

Dianema corticatum Lister [DNMcor, O, 12/0] PICb: 3, PIN: 9; W: 12; LOC. 21, 22, 27, 29, 33; LE306240... Fig. $2 \mathrm{~h}$.

Occuring in small colonies of depressed sporocarps on medium-decayed coniferous wood without bark. The yellowish, cartilaginous peridium is very typical and allows to assign to this species even remnants of fructifications from the previous year.

Dianema harveyi Rex [DNMhar, R, 1/0] PICa: 1; W: 1; LOC. 14; LE307822.

Occurring in the same habitat as the previous species, but much rarer.

Dianema repens G. Lister \& Cran [DNMrep, R, 3/0] PIN: 3; W: 3; LOC. 21; LE307686.

Occurring in the same habitat as $D$. corticatum, but probably rarer and/or less conspicuous due to the dull greyish-brown spore mass in small sporocarps. 

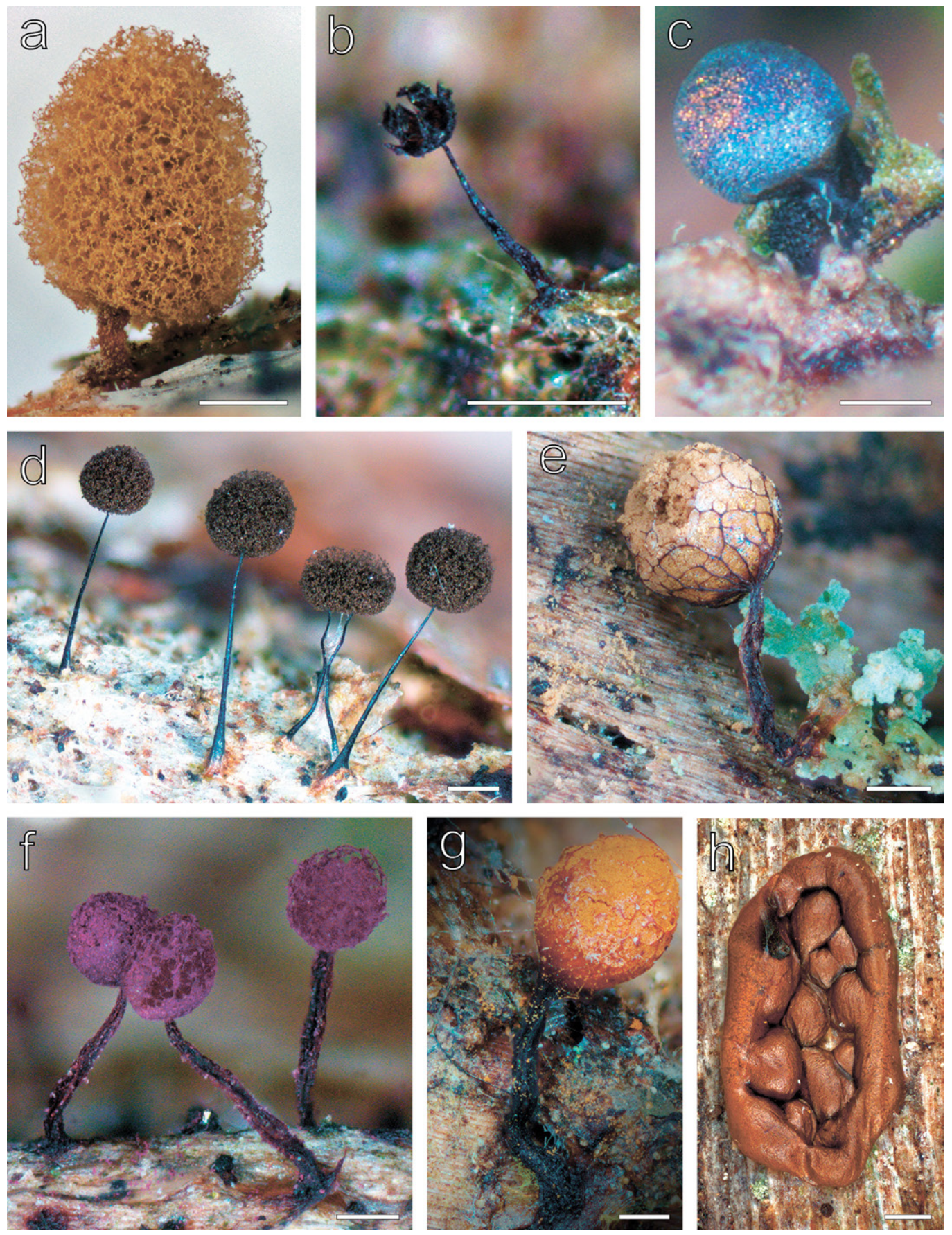

Fig. 2. Morphological traits of sporocarps of encountered myxomycete species as seen under the dissecting microscope. a: Arcyria pomiformis (LE306331), b: Barbeyella minutissima (LE306496, DM),

c: Colloderma oculatum (LE306499), d: Comatricha nigra (LE306327), e: Cribraria macrocarpa (LE306234), f: Cribraria purpurea (LE306614), g: Cribraria rufa (LE306214), h: Dianema corticatum (LE306337). Scale bars: $a-g=200 \mu \mathrm{m}, \mathrm{h}=500 \mu \mathrm{m}$. 
Khi Diderma alpinum (Meyl.) Meyl. [DIDalp, R, 8/0] SB: 8; L: 8; LOC. 3, 4, 6, 7, 8; LE305754...

All specimens are recognizable by plasmodiocarps growing densely together and sharing a conspicuous white hypothallus with a broad margin, with a matt white outer peridium layer densely adhering to the inner layer and the hypothallus.

Diderma montanum (Meyl.) Meyl. [DIDmon, R, 1/0] PIN: 1; W: 1; LOC. 22; LE306423.

Khi Diderma niveum (Rostaf.) T. Macbr. [DIDniv, C, 26/0] SB: 26; L: 26; LOC. 3, 4, 6, 8, 17; LE305733...

All specimens possess sporocarps with a dark ferruginous columella.

Diderma radiatum (L.) Morgan [DIDrad, O, 16/0] PICa: 9, PICb: 6, PIN: 1; W: 16; LOC. 14, 21, 25, 30, 33, 38, 41, 43, 44; LE306220...

Diderma rugosum (Rex) T. Macbr. [DIDrug, R, 1/0] PICb: 1; W: 1; LOC. 30; LE307714.

Diderma umbilicatum Pers. [DIDumb, R, 2/0] PICa: 1; PIN: 1; W: 2; LOC. 14, 21; LE306126, 306464.

Didymium difforme (Pers.) Gray [DDYdif, R, 0/2] SB: 2; D: 2; LOC. 1; LE306964...

Didymium melanospermum (Pers.) T. Macbr. [DDYmel, C, 27/0] PICa: 5, PICb: 15, PIN: 7; L: 1, W: 26; LOC. 14, 21, 22, 27, 31, 33, 34, 35, 36, 41, 42, 43; LE306228...

Didymium squamulosum (Alb. \& Schwein.) Fr. [DDYsqu, O, 15/0] PICa: 15; L: 15; LOC. 20; LE306041...

Enerthenema papillatum (Pers.) Rostaf. [ENEpap, O, 23/0] PICa: 4, PICb: 3, PIN: 16; W: 23; LOC. 20, 21, 22, 23, 33, 43; LE306040...

This lignicolous species is often associated with Arcyria pomiformis, Comatricha nigra and Licea minima. It forms sporocarps on large spruce and pine logs in dry open forest.

Fuligo leviderma $\mathrm{H}$. Neubert, Nowotny \& $\mathrm{K}$. Baumann [FULlev, R, 1/0] PIN: 1; W: 1; LOC. 23; LE306810.

Fuligo muscorum Alb. \& Schwein. [FULmus, R, 3/0] PICa: 1, PICb: 2; L: 3; LOC. 27, 33, 36; LE319311..., Fig. 3a, b.

This species forms large sporocarps on living ferns, grasses and adjacent bryophytes, where bright orange plasmodium moves up from ground litter.

Fuligo septica var. candida (Pers.) R.E. Fr. [FULcan, R, 7/0] PICa: 2, PICb: 5; W: 4, L: 3; LOC. 14, 28; LE307766...
Fuligo septica (L.) F.H. Wigg. [FULsep, R, 3/0] PICa: 2, PIN: 1; W: 3; LOC. 14, 23; LE319312...

Hemitrichia clavata (Pers.) Rostaf. [HEMcla, R, 5/0] PICa: 3, PICb: 1, PIN: 1; W: 5; LOC. 14, 22, 28; LE306144...

${ }^{\mathrm{Khi}}$ Lamproderma arcyrioides (Sommerf.) Rostaf. [LAMarc, O, 10, 10/0] SB: 10; liv: 10; LOC. 4; LE305736...

Khi Lamproderma cacographicum Bozonnet, Mar. Mey. \& Poulain [LAMcac, R, 1/0] SB: 1; liv: 1; LOC. 4; LE305744.

Lamproderma columbinum (Pers.) Rostaf. [LAMcol, O, 15/0] PICa: 6, PICb: 9; W: 15; LOC. 14, 25, 30, 35, 38, 43; LE30650042..., Fig. 3c.

Khi Lamproderma maculatum Kowalski [LAMmac, R, 6/0] SB: 6; L: 6; LOC. 5, 17; LE305776...Fig. 3d.

${ }^{K h i}$ Lamproderma ovoideum Meyl. [LAMovo, O, 14/0] SB: 14; L: 14; LOC. 3, 4, 17; LE305758...

Lamproderma zonatum Mar. Mey. \& Poulain [LAMzon, R, 3/0] SB: 3; L: 3; LOC. 12, 17; LE305840..., Fig. 3 e.

It is the first record of this species in Fennoskandia. The specimens have typical sessile, ellipsoid sporocarps $0.5-1.5 \mathrm{~mm}$ wide, blue with bronze shining zone (Fig. 3e); they are very similar to specimens found in the Leningrad region (Erastova \& Novozhilov 2015). Columella reaching $1 / 2$ to $2 / 3$ of the height of the sporocarp. Capillitium dense, with finer threads at the periphery. Spores pale brown to moderately dark (10.5-)11-13.5(-14) $\mu \mathrm{m}$, warted or finely spinulose with a rather dense, regularly distributed ornamentation.

Leocarpus fragilis (Dicks.) Rostaf. [LEOfra, C, 26/0] PICb: 12, PICa: 7, PIN: 7; L: 2, W: 24; LOC. 14, 21, 22, 27, 31, 33, 34, 36, 37, 43; LE 306192...

${ }^{K h}$ Lepidoderma carestianum (Rabenh.) Rostaf. [LEPcar, R, 4/0] SB: 4; L: 4; LOC. 3, 4; LE305766...

${ }_{\text {Khi }}$ Lepidoderma chailletii Rostaf. [LEPcha, O, 16/0] SB: 16; L: 3, L: 13; LOC. 2, 3, 4, 5, 10, 11, 17, 18; LE305731...

Lepidoderma tigrinum (Schrad.) Rostaf. [LEPtig, R, 3/0] PICa: 1, PICb: 1, PIN: 1; w: 3; LOC. 21, 30, 35; LE306452...

Licea chelonoides Nann.-Bremek. [LICche, R, 1/0] PIN: 1; W: 1; LOC. 21; LE319290.

Licea minima Fr. [LICmin, O, 14/4] SB: 1, PICa: 7, PICb: 2, PIN: 8; L: 1, W: 17; LOC. 4, 14, 15, 16, 21 , 30, 35; LE307656... 
Licea nannengae Pando \& Lado [LICnan, R, 0/1] SB: 1; L: 1; LOC. 1; LE306974.

Licea pusilla Schrad. [LICpus, O, 19/2] SB: 1, PICa: 5, PICb: 8, PIN: 7; L: 2, W: 19; LOC. 1, 15, 21, 23 , 29, 37, 43; LE306307...

Licea pygmaea (Meyl.) Ing [LICpyg, C, 41/6] PICa: 24, PICb: 16, PIN: 7; W: 47; LOC. 14, 15, 16, 20 , 21, 22, 23, 24, 25, 27, 30, 37, 38, 41, 42, 43; LE306074...

Licea variabilis Schrad. [LICvar, A, 61/0] PICa: 26, PICb: 13, PIN: 22; W: 61; LOC. 14, 20, 21, 22, 23, 25, 29, 30, 33, 35, 37, 39, 41, 42, 43; LE306085...

Lindbladia tubulina Fr. [R, 1, 1/0] PICb: 1; W: 1; LOC. 30; LE307554.

Lycogala epidendrum (L.) Fr. [LYCepi, A, 58/0] PICa: 12, PICb: 20, PIN: 26; W: 58; LOC. 14, 20, 21, 22, 23, 25, 27, 28, 30, 33, 34, 35, 41, 43; LE306031...

${ }^{K h i}$ Meriderma aggregatum ad int. (Meyl.) Mar. Mey. \& Poulain [MERagg, R, 1/0] SB: 1; L: 1; LOC. 3; LE305771.

Metatrichia floriformis (Schwein.) Nann.Bremek. [METflo, R, 1/0] PICa: 1; W: 1; LOC. 35; LE307632.

Metatrichia vesparia (Batsch) Nann.-Bremek. ex G. W. Martin \& Alexop [METves, R, 1/0] PICa: 1; W: 1; LOC. 14; LE306173.

Paradiacheopsis fimbriata (G. Lister \& Cran) Hertel ex Nann.-Bremek. [PARfim, O, 0/12] SB: 7, PICa: 5; B: 9, W: 3; LOC. 1, 16, 18; LE306961...

Paradiacheopsis solitaria (Nann.-Bremek.) Nann.-Bremek. [PARsol, R, 0/1] SB: 1; B: 1; LOC. 18; LE319313.

Perichaena chrysosperma (Curr.) Lister [PERchr, R, 0/3] SB: 3; B: 3; LOC. 1, 4; LE307248...

Perichaena corticalis (Batsch) Rostaf. [PERcor, R, 0/1] SB: 1; B: 1; LOC. 4; LE306989.

Perichaena vermicularis (Schwein.) Rostaf. [PERver, R, 2/1] SB: 1, PICa: 2; B: 1, W: 2; LOC. 1, 14; LE307767...

Khi Physarum albescens Ellis ex T. Macbr. [PHYalb, C, 26/0] SB: 26; L: 26; LOC. 5, 6, 7, 8, 9, 13, 17; LE305803...

This was the most abundant nivicolous myxomycete in subalpine birch forests of the reserve. All collections show a morphology identical with that of specimens found recently in the Khibiny Mts. (Erastova et al. 2017) and are already recognizable in the field by their large, subglobose to obovoid sporocarps on weak stalks formed by strands of the hypothallus and the variegated color of lime at the peridium surface ranging from yellow to pale orange (limeless specimens appear dark blue and iridescent).

Physarum album (Bull.) Chevall. [PHYalu, A, 177/0] PICa: 64, PICb: 93, PIN: 20; W: 177; LOC. 14, $19,20,21,22,23,24,25,27,28,29,30,31,33,34,35$, 37, 38, 39, 40, 41, 42, 43; LE306060...

Physarum cinereum (Batsch) Pers. [PHYcin, R, 2/0] PICa: 2; L: 1, W: 1; LOC. 14, 20; LE306048...

Physarum compressum Alb. \& Schwein. [PHYcom, O, 0/15] SB: 9, PICa: 6; B: 5, D: 10; LOC. 1, 4, 16; LE306955..., Fig. 3 f.

This species is one of the most common species in the reserve, appearing in moist chamber cultures on droppings of willow ptarmigan and moose. This species was frequently registered in different regions on dung of birds which feed on seeds, buds or other plant parts (Eliasson \& Lundqvist 1979, Eliasson 2013).

Physarum confertum T. Macbr. [PHYcon, R, 1/0] PICb: 1; L: 1; LOC. 28; LE306512.

Physarum globuliferum (Bull.) Pers. [PHYglo, R, 1/0] PICa: 1; W: 1; LOC. 39; LE306611.

Physarum gyrosum Rostaf. [PHYgyr, R, 1/0] PICa: 1; W: 1; LOC. 14; LE307844.

Physarum lateritium (Berk. \& Ravenel) Morgan [PHYlat, R, 1/0] PICb: 1; L: 1; LOC. 31. LE307701.

Physarum leucopus Link [PHYlcp, R, 1/0] PICb: 1; W: 1; LOC. 43; LE306693.

Physarum leucophaeum Fr. [PHYlph, C, 27/1] SB: 1, PICa: 8, PICb: 10, PIN: 9; L: 1, W: 27; LOC. 4, 14, 20, 21, 22, 23, 31, 34, 41; LE306202...

Physarum notabile T. Macbr. [PHYnot, R, 2/0] PICa: 2; W: 2; LOC. 14, 34; LE306263...

Physarum pusillum (Berk. \& M. A. Curtis) G. Lister [PHYpus, R, 0/1] SB: 1; B: 1; LOC. 4; LE306982.

Physarum rubiginosum Fr. [PHYrub, R, 1/0] PICa: 1; W: 1; LOC. 14; LE306143.

Physarum viride (Bull.) Pers. [PHYvde, A, 73/0] SB: 2, PICa: 29, PICb: 33, PIN: 9; L: 1, W: 72; LOC. 14, 19, 20, 21, 22, 27, 28, 30, 33, 34, 35, 37, 38, 39, 40, 41, 42, 43, 44; LE306038...

Physarum virescens Ditmar [PHYvir, R, 1, 1/0] PIN: 1; W: 1; LOC. 21 ; LE307672.

Siphoptychium reticulatum Leontyev, Schnittler et S.L. Stephenson [SIPret, R, 1, 1/0] PICb: 1; W: 1; LOC. 28; LE306515, Fig. 3g. 
We found only one pseudoaethalium on strongly decomposed wood of spruce, which is very similar with the type description of $S$. reticulatum (Leontyev et al. 2019). The key characters of the species are slightly convex, polygonal sporothecal tips (0.3-)0.5-0.7(-1.0) $\mathrm{mm}$ diam., with bright lines between sporothecal tips, giving the pseudoaethalial surface a reticulate appearance. This taxon was so far most likely recorded in Russia as Tubifera dictyoderma (Novozhilov et al., 2017); detailed investigations have to be carried out to ascertain if both species occur in Russia.

Stemonaria laxiretis Nann.-Bremek. \& Y. Yamam. [STAlax, R, 3/0] PICa: 3; W: 3; Loc. 20; LE306034...

Our specimens fit well the type description of this species (Nannenga-Bremekamp \& Yamamoto 1990) and are characterized by lax, rather slender capillitial threads with some dark membranous expansions, constituting a lax internal net of one or two meshes across the radius with many long free ends.

Stemonitis axifera (Bull.) T. Macbr. [STEaxi, C, 46/0] PICa: 16, PICb: 24, PIN: 6; W: 46; LOC. 14, 21, 23, 27, 30, 33, 34, 37, 38, 40, 41, 42, 43; LE306169...

Stemonitis capillitionodosa G. Moreno, D.W. Mitch., C. Rojas \& S.L. Stephenson [STEcap, R, 2/0] PICb: 2; W: 2; LOC. 33; LE306548, 306833.

We found this rare species twice; both specimens possess a typical columella with expansions at the apex and large, densely spinulose spores (9-11 $\mu \mathrm{m}$ diam.). If observed under SEM, these spinules appear as coral-like warts (Vlasenko et al. 2020). Previously one sequence of this species (LE306548) was submitted to GenBank under No. MH930789 but with the incorrect determination Stemonitis laxifila (Shchepin et al. 2019). A phylogenetic analysis of the $18 \mathrm{~S}$ rDNA sequences (SSU) revealed 100\% similarity with the studied specimen of $S$. capillitionodosa (LE306833, GenBank No. MN610391). The SEM study of these specimens confirmed that both specimens belong to $S$. capillitionodosa, characterized by the unique ornamentation of its spores in the form of coral-shaped warts (Vlasenko et al. 2020).

Stemonitis fusca Roth [STEfus, R, 6/2] SB: 2, PICa: 3, PICb: 2, PIN: 1; B: 2, W: 6; LOC. 1, 14, 21, 31, 33; LE306270...

Stemonitis lignicola Nann.-Bremek. [STElig, O, 11/0] PICb: 6, PIN: 5; W: 11; LOC. 21, 23, 28, 30, 31; LE306501...
Stemonitis pallida Wingate [STEpal, R, 2/0] PICa: 1, PIN: 1; W: 2; LOC. 21, 39; LE306297...

Stemonitis smithii T. Macbr. [STEsmi, R, 6/0] PICa: 1, PICb: 3, PIN: 2; W: 6; LOC. 20, 21, 22, 30, 43; LE306069...

Stemonitis splendens Rostaf. [STEspl, R, 2/0] PIN: 2; W: 2; LOC. 21; LE306296...

Stemonitopsis aequalis (Peck) Y. Yamam. [STEaeq, O, 17/0] PICa: 2, PICb: 9, PIN: 6; W: 17; LOC. 21 , 28, 29, 30, 33, 35, 37, 43; LE306319..

Stemonitopsis amoena (Nann.-Bremek.) Nann.-Bremek. [STEamo, R, 4/0] PIN: 4; W: 4; LOC. 21, 22; LE306317...

Stemonitopsis gracilis (G. Lister) Nann.Bremek. [STEgra, R, 5/0] PICa: 1, PICb: 1, PIN: 3; W: 5; LOC. 21, 22, 27, 34; LE306236...

Stemonitopsis hyperopta (Meyl.) Nann.Bremek. [STEhyp, A, 53/0] PICa: 11, PICb: 23, PIN: 19; W: 53; LOC. 14, 21, 22, 23, 27, 28, 29, 30, 33, 34, 37, 39, 41, 42, 43; LE306182...

Stemonitopsis typhina (F.H. Wigg.) Nann.Bremek. [STEtyp, C, 26/0] PICa: 13, PICb: 10, PIN: 3; W: 26; LOC. 14, 21, 22, 30, 31, 36, 41; LE306123...

Symphytocarpus flaccidus (Lister) Ing \& Nann.-Bremek. [SYMfla, R, 1/0] PIN: 1; W: 1; LOC. 23; LE307636.

Trichia botrytis (J.F. Gmel.) Pers. [TRIbot, C, 42/0] PICa: 15, PICb: 23, PIN: 4; W: 42; LOc. 14, 20 , 21, 28, 30, 33, 34, 37, 39, 41, 42, 43, 44; LE306071...

Trichia contorta (Ditmar) Rostaf. [TRIcon, R, 3/0] PICa: 1, PICb: 2; W: 3; LOC. 14, 31; LE306582...

Trichia decipiens (Pers.) T. Macbr. [TRIdec, C, 34/0] PICa: 21, PICb: 13, ; W: 34; LOC. 14, 20, 30, 33, 34, 35, 41, 42, 43; LE306033...

Trichia erecta Rex [TRIere, R, 4/0] PICa: 3, PICb: 1, ; W: 4; LOC. 14, 31; LE306149...

Trichia favoginea (Batsch) Pers. [TRIfav, R, 5/0] PICa: 5; W: 5; LOC. 14, 25, 38, 44; LE306171...

Trichia lutescens (Lister) Lister [TRIlut, R, 1/0] PIN: 1; W: 1; LOC. 22; LE306404.

Trichia persimilis P. Karst. [TRIper, R, 7/0] PICa: 3, PICb: 1, PIN: 3; W: 7; LOC. 14, 20, 22, 23, 43; LE306032...

Trichia scabra Rostaf. [TRIsca, R, 7/0] PICa: 1, PICb: 4, PIN: 2; W: 7; LOC. 14, 22, 31; LE306258...

Trichia sordida Johannesen [TRIsor, R, 1/0] SB: 1, L: 1; LOC. 3; LE305783, Fig. 3 h.

In spite of intensive previous studies in the 


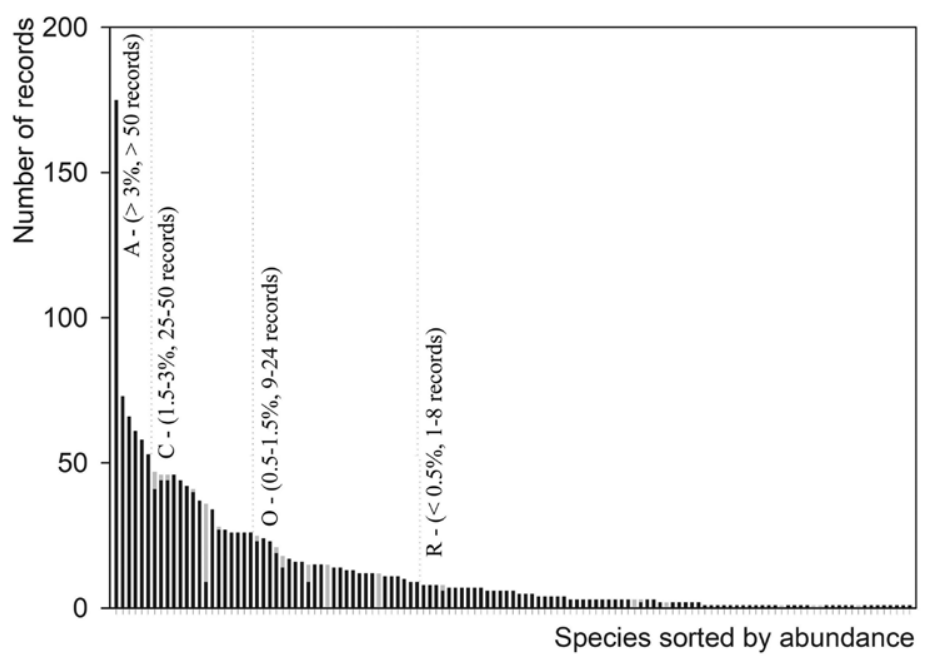

Fig. 4. Frequency distribution of all 1675 determinable records of myxomycetes from 125 taxa. The black sections of the bars indicate records collected in the field, whereas the grey sections indicate records from 210 moist chamber cultures. Three thin vertical dotted lines show the delimitation of the ACOR classes.

Khibiny Mts. (Erastova et al. 2017), this nivicolous species was not registered and appears to be a rare species in the study area. Our specimen is a small colony of sessile dull ochraceous sporangia with dark lines and spots. The capillitium represents smooth elaters with long gradually tapering tips. Large, densely warted spores fit well to the typical description of the species (Johannesen 1984b).

Trichia subfusca Rex [TRIsub, R, 1/0] PICb: 1; W: 1; LOC. 33; LE307623.

Trichia varia (Pers. ex J.F.Gmel.) Pers. [TRIvar, C, 44/0] PICa: 19, PICb: 16, PIN: 9; W: 43, L: 1; LOC. 14, 20, 22, 23, 24, 26, 27, 28, 31, 33, 35, 37, 39, 41, 42, 44; LE306062...

Tubifera applanata (Leontyev \& Fefelov) Leontyev \& Fefelov [TUBapp, R, 1/0] PICa: 1; W: 1; LOC. 35; LE306573.

Our collection is represented by one pseudoaethalium with the typical sporothecal tips which are isodiametric, roughly hexagonal, similar to each other in size and occur in regular rows (Leontyev et al. 2015).

Tubifera ferruginosa (Batsch) J.F. Gmel. [O, 13, 13/0] PICa: 4, PICb: 3, PIN: 6; w: 13; LOC. 14, 21, 23, 25, 30, 43, 44; LE306186...
Species diversity

The species list given above was compiled from 1675 records of myxomycetes. Of these, 1583 were recorded in the field, whereas the other 92 records were obtained from 210 moist chamber cultures. In total, 124 morphospecies and one variety belonging to 34 genera were identified, all recorded as new for the Laplandskiy Reserve. Most taxa were collected in the field (117); only 21 species were recorded in moist chamber (with 13 taxa retrieved by both methods). This is reflected by the proportions of species found exclusively in the field (103 morphospecies and one variety of 32 genera, $83.2 \%$ ) or in moist chambers ( 8 species of 5 genera, $5.6 \%$ ); the remaining species (13 species of 7 genera, $8.8 \%$ ) were recorded with both methods. Non-fruiting plasmodia and sclerotia were not included in these numbers (114 records).

Therefore, records from the field and from the moist chamber cultures largely complemented each other (Fig. 4). Sixty two percent of all taxa (77) were classified as rare for the whole study area $(<0.5 \%$ of all records); most were represented by only one (33) or two (7) records. Abundant species ( $>3 \%$ of 

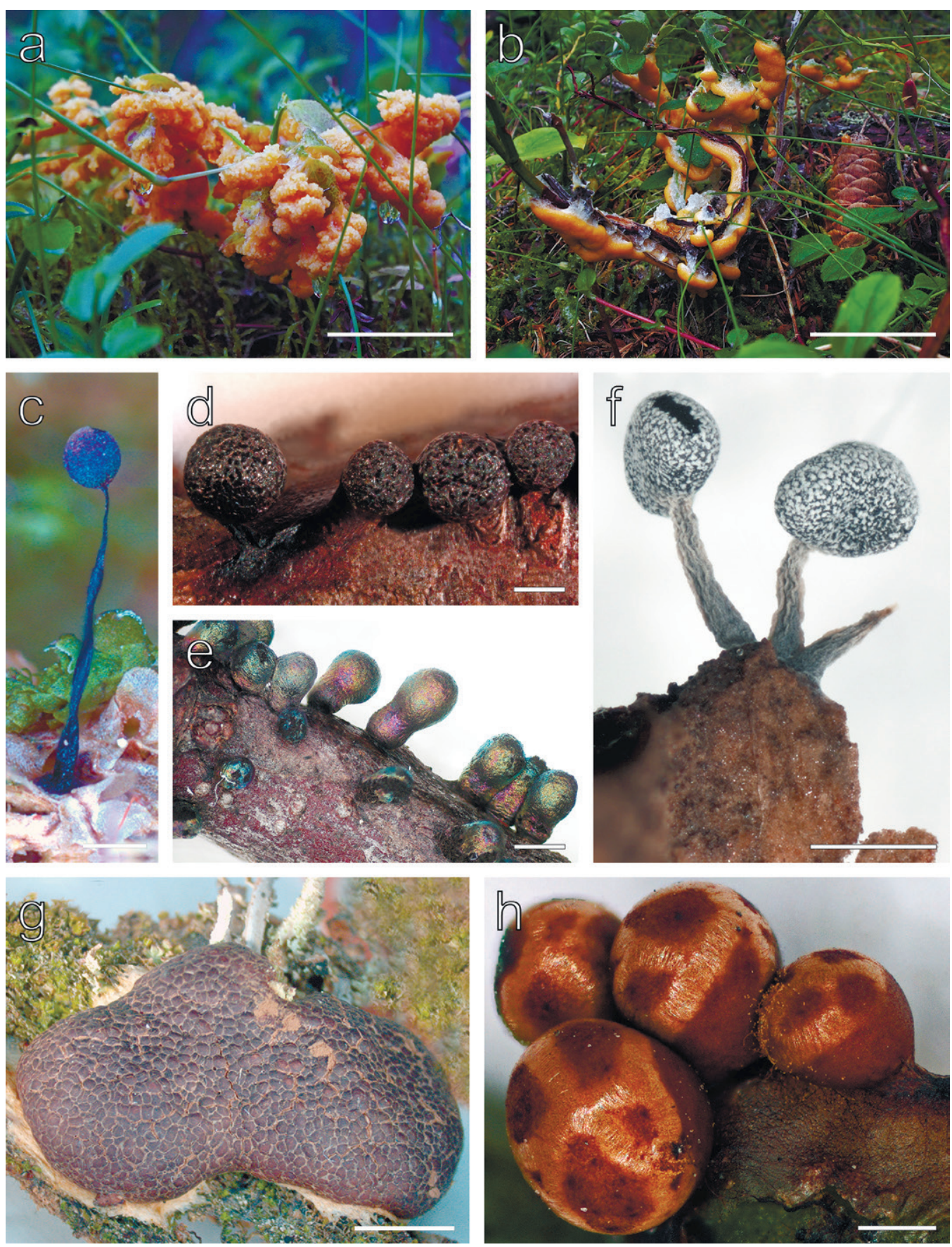

Fig. 3. Morphological traits of sporocarps of encountered myxomycete species. a, b: Fuligo muscorum (LE319311), a: plasmodium on living grasses, b: immature sporocarps on living grasses, C: Lamproderma columbinum (LE306500), sporocarp as seen under dissecting microscope (DM), d: Lamproderma maculatum (LE305776, DM), e: Lamproderma zonatum (LE305840), f: Physarum compressum (LE306955, DM), g: Siphoptychium reticulatum (LE306515, DM), h: Trichia sordida (LE305783, DM). Scale bars: a, b = 3 cm, c = $200 \mu \mathrm{m}, \mathrm{d}, \mathrm{e}, \mathrm{f}, \mathrm{h}=500 \mu \mathrm{m}, \mathrm{g}=1 \mathrm{~cm}$. 
all records) included Colloderma oculatum, Licea variabilis, Lycogala epidendrum, Physarum album, Ph. viride, and Stemonitopsis hyperopta. The following species were classified as common (1.5-3\% of all records): Arcyria cinerea, A. incarnata, Comatricha nigra, Cribraria cancellata, C. oregana, Diderma niveum, Didymium melanospermum, Leocarpus fragilis, Licea pygmaea, Physarum albescens, Ph. leucophaeum, Stemonitis axifera, Stemonitopsis typhoides, Trichia botrytis, T. decipiens, and T. varia. A few species, including Arcyria cinerea, Cribraria microcarpa, Licea pygmaea, Paradiacheopsis fimbriata, and Physarum compressum, were observed most often in moist chamber cultures (Fig. 4).

\section{Efficiency and completeness of the survey}

For the study as a whole, values of Chaol estimator (Fig. 5a, Table 1) suggest that in spite of 28 days of field work in the reserve spread over June, July and August of different years, our effort was not sufficient to recover all species (125 taxa from 1675 records, completeness $66 \%$, all figures given according to the final figure of the Chaol estimator). However, a part of this relative incompleteness is due to the different species assemblages recovered by the two different survey methods used (field collecting and moist chambers). Figures for completeness increase if we look at these two methods separately ( field collecting: 117 taxa from 1584 records, 70\%; moist chambers: 21 taxa from 92 records, $78 \%$ ).

If we look at the species assemblages recovered from the field (ca. 95\% of all records), all four forest types seem to be exhaustively sampled (fc: PICa: 82 taxa from 546 records, completeness according to the Chaol estimator 84\%; PICb: 70 taxa from 540 records, 84\%; PIN: 62 taxa from 381 records, $83 \%$; SB: 13 taxa from 116 records, 87\%, Fig. 5a, Table 1). The rarified data (at level of 116 records) show a similar trend: PICa 46 taxa, 47\%, PICb 41 taxa, 67\%, PIN 43 taxa, $73 \%$ and SB 13 taxa. However, since we have no data obtained from moist chamber cultures for $\mathrm{PICb}$ and PIN and we were not able to visit PIN and SB throughout the field season, the species richness and diversity were likely to be underestimated in these vegetation types. We will address these sources of error within future investigations.
Seen in total, the main substrate types were rather exhaustively sampled (Fig. 5b), but the completeness varies greatly for different types of substrates, depending on the collection method. Most exhaustively sampled was coarse woody debris (w): 102 taxa, 1466 records, $88 \%$ completeness, Table 2. For this substrate type, the moist chamber culture method did not reveal additional information: all of the 8 species (25 records) recorded were as well observed in the field. In contrast, this method is indispensable for corticolous (10 taxa, 37 records) and coprophilous (3 taxa, 21 records) myxomycetes, where all taxa were exclusively observed in moist chamber.

Myxomycete diversity within vegetation types of the reserve

At least when judged by fructification propensity, myxomycetes are to some degree specialized on vegetation (forest association) and substrate type. Despite the high number of 125 taxa recorded, only 16 were found to be widely distributed (present in 10 or more of the 44 studied localities, Database S1). For field records, both species richness and diversity increased significantly from subalpine birch forest (SB: 13 species, $\mathrm{H}^{\prime}=2.1, \mathrm{D}=6.9$ ) over open dry spruce-pine forest (PIN: $62, \mathrm{H}^{\prime}=3.7, \mathrm{D}=30.0$ ) to the two associations of spruce forest (PICb: 70 species, $\mathrm{H}^{\prime}=3.5, \mathrm{D}=19.1$; PICa: 82 species, $\mathrm{H}^{\prime}=3.8, \mathrm{D}=28$; Fig. 5a, Table 1).

Most of the abundant myxomycete species occurred in two or three forest types of the reserve, although preferences were visible in some cases. Only in the subalpine birch forest (SB) we could reveal nivicolous myxomycetes. Common species found in SB and confined exclusively to litter and stems of living dwarf shrubs were Diderma niveum (15\% of 170 records of all found species), Physarum albescens (14\%), Lepidoderma chailletii (9\%), and Lamproderma ovoideum (8\%). All these nivicolous species are widely distributed in subalpine communities and mountain alpine tundra (Erastova et al. 2017) and appear to be abundant in mountain regions (Ronikier \& Ronikier 2009).

None of the very common myxomycete species (abundance according to the ACOR scale $>3 \%$ of all records) was recorded exclusively in only one forest type. The most common lignicolous species in the reserve is Physarum album (11\% of 1675 re- 

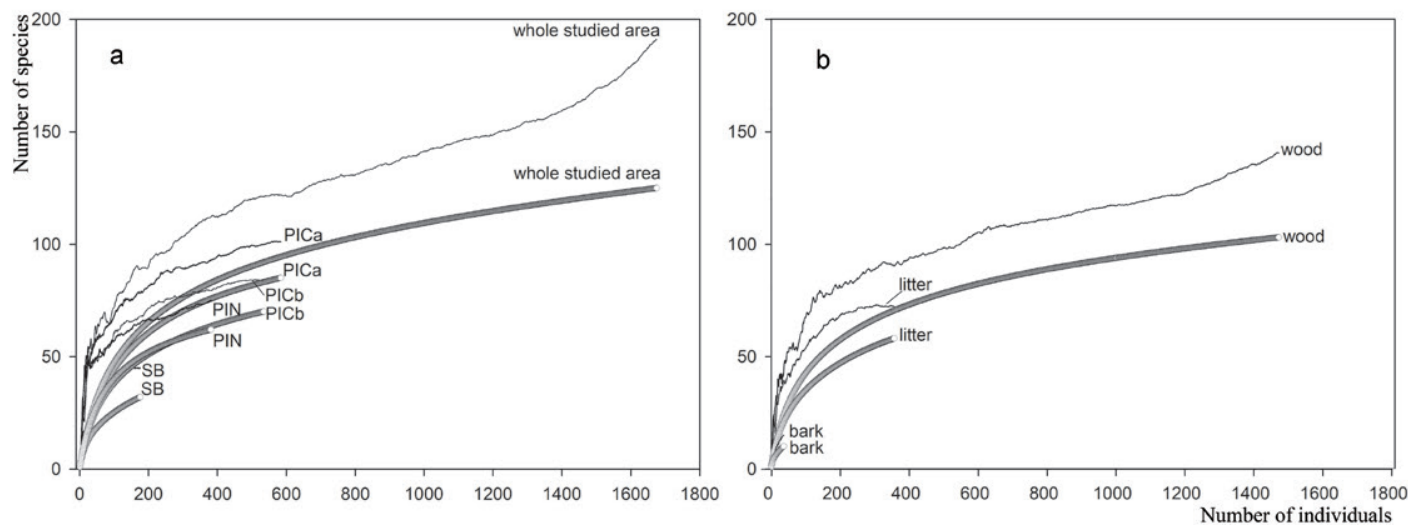

Fig. 5. Individual-based species accumulation curves (thick lines) and the Chao 1 estimator (thin jagged lines) of expected morphospecies richness; a: for the whole studied area and for the four forest types (only field specimens considered; PICa - spruce forest, PICb - spruce-peat moss forest, PIN - dry spruce-pine forest, SB - subalpine birch forest); b: for the three studied substrate types (b - bark, w - wood, I - ground litter).

Table 1. Statistical data for myxomycetes of the Laplandskiy Reserve obtained using field collections ( $\mathrm{fc}_{\mathrm{c}}$ ) and moist chamber cultures (mc), grouped according to the four major vegetation associations: subalpine birch forest (SB), spruce forest (PICa), spruce-peat moss forest (PICb), and dry spruce-pine forest (PIN).

\begin{tabular}{|c|c|c|c|c|c|}
\hline & PIN & $\mathrm{PICa}$ & $\mathrm{PICb}$ & SB & Whole area \\
\hline Elevation range (m a.s.l.) & $35-190$ & $110-300$ & $120-370$ & $340-520$ & $35-520$ \\
\hline Main canopy tree species & PIN & $\mathrm{PIC}$ & $\mathrm{PIC}$ & BET & $\mathrm{PIC}$ \\
\hline Sampled localities & 4 & 13 & 12 & 15 & 44 \\
\hline Records (fc/mc) & $381 / N D$ & $546 / 38$ & $540 / N D$ & $116 / 54$ & $1583 / 92$ \\
\hline Species (fc/mc) & $62(62 / N D)$ & $84(82 / 10)$ & $70 / \mathrm{ND}$ & $30(13 / 17)$ & $125(117 / 21)$ \\
\hline Chaol \pm SD $^{2}$ & $75 \pm 9$ & $98 \pm 9$ & $84 \pm 9$ & $15 \pm 3$ & $191 \pm 33$ \\
\hline Genera (fc/mc) & $27 / N D$ & $34(30 / 5)$ & $7 / \mathrm{ND}$ & $14(14 / 8)$ & $34(33 / 9)$ \\
\hline Species/Genera & 2.7 & 2.8 & 2.6 & 2.1 & 3.7 \\
\hline Shannon $H^{\prime}\left(f_{c}\right)$ & 3.7 & $3.9(3.8)$ & 3.5 & $2.8(2.2)$ & 4.1 \\
\hline Simpson's D ( $\left.f_{c}\right)$ & 30 & $30(28)$ & 19 & $12(6.7)$ & 35 \\
\hline Number of mc & ND & 90 & ND & 120 & 210 \\
\hline$\%$ mc positive ${ }^{1}$ & ND & 48 & ND & 60 & 34 \\
\hline
\end{tabular}

${ }^{1}$ Only cultures that yielded sporocarps were counted as positive. BET - Betula czerepanovii, PIC - Picea obovata, PIN - Pinus sylvestris. ${ }^{2}$ The Chaol estimator for forest types were calculated for the field collections only, whereas for the whole area both sets of data (field collections and moist chamber cultures) were used. ND = no data. 
cords). The most specialized lignicolous species in pure spruce forests are Lamproderma columbinum (spruce wood, PICa: 6, PICb: 9 records), Colloderma oculatum (spruce wood, PICa: 28, PICb: 32 records) and Barbeyella minutissima (PICa: 2, PICb: 6 records). The most common species of the dry sprucepine forest (PIN) are Lycogala epidendrum (45\% of 58 records of this species), Comatricha nigra (50\% of 46), Licea variabilis (36\% of 61), Arcyria pomiformis (76\% of 25), Enerthenema papillatum (70\% of 23 ), Cribraria oregana (37\% of 46), and Stemonitopsis hyperopta (36\% of 53$)$.

The overall diversity and the degree of specialization in species show opposite trends. A comparison based on adjusted incidence-based ChaoSørensen similarity $\left(\mathrm{C}_{\mathrm{cs}}\right)$ revealed the myxomycete assemblages of the two forest associations poorest in species to be the most distinctive (SB: 30 species, mean $\mathrm{C}_{\mathrm{cs}}=0.12 \pm 0.03$; PIN 62 species, mean $\mathrm{C}_{\mathrm{cs}}$
$=0.59 \pm 0.02$; Table 3 ). The main reason is likely the general rarity of acidophilic and bryophilic myxomycete species in these two communities. Many species require for development the thick mats of mosses often covering large logs of spruce and do not fruit on the rather dry wood prevailing in SB and PIN. In addition, nivicolous myxomycetes are a distinct component of the subalpine forests (SB).

A view from the opposite side presents the analysis of the indicator values of species (Fig. 6, Table S1). Here, the two rather moist forest associations (PICa and $\mathrm{PICb}$ ) have the lowest number of indicator species, the dry spruce-pine forest (PIN) the highest. Probably, most species can fruit in the rather dense and moist spruce forest, whereas only specialized species can cope with the overall lower moisture supply in the two other habitats (PIN and SB) where the ground layer retains less water due to the rather open canopy and the lower moss biomass. In the

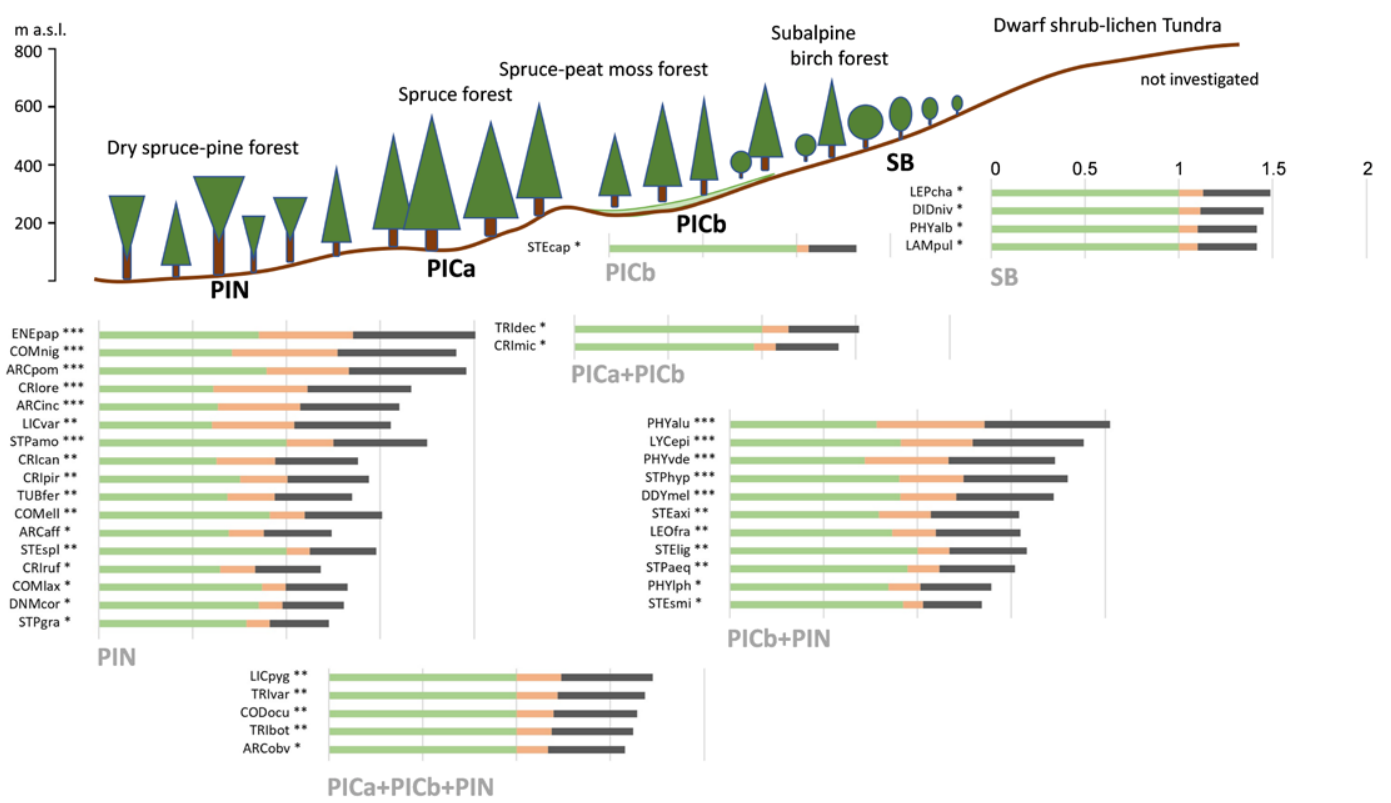

Fig. 6. Schematic view of the forest associations and their typical myxomycete species revealed by an indicator value analysis, sorted according to significance of indicator values ( $p$ value $<0.05^{*},<0.01^{* *},<0.001^{* * *}$ ). Three types of indicator values were calculated and stacked in the graphical visualization: the probability that the surveyed site belongs to the target site group given the fact that the species has been found (component $A$, green bars), the probability of finding the species in sites belonging to the site group (component B, ochraceous bars), and IndVal.g influenced by both components (black bars). Abbreviations for myxomycete species and forest associations are indicated in the annotated species list and in Material and Methods, correspondingly. 
analysis, these specialized species appear with rather high indicator values (PIN: lignicolous species growing on rather dry wood, SB: nivicolous species developing in soil under long-lasting snowpatches).

\section{Substrate-species relationships}

The overall degree of specialization of myxomycetes is higher for substrate type than for forest associations. With respect to the major substrate types studied, diversity and species richness increased from dung ( 3 species, $\mathrm{H}^{\prime}=0.9, \mathrm{D}=2.4, \mathrm{Sp} / \mathrm{G}=1.0$ ) and bark (10 species, $\mathrm{H}^{\prime}=1.8, \mathrm{D}=4.7, \mathrm{Sp} / \mathrm{G}=1.7$ ) over litter $\left(29\right.$ species, $\mathrm{H}^{\prime}=2.7, \mathrm{D}=10.5, \mathrm{Sp} / \mathrm{G}=$ $3.2)$ to wood (103 species, $\mathrm{H}^{\prime}=3.9, \mathrm{D}=28.7, \mathrm{Sp} / \mathrm{G}=$ 3.2). This pattern basically remains the same when comparing the individual-based species accumulation curves (rarefied values for species richness at the level of 21 records: dung 3, bark 8 , litter 14, and wood 16, see Fig. 5b). The similarity between the myxomycete assemblages associated with different substrates in the reserve was very low $\left(\right.$ mean $\mathrm{C}_{\mathrm{cs}}=$ $0.15 \pm 0.09$, Table 3 ).

Wood-inhabiting (lignicolous) myxomycetes represented the largest myxomycete assemblage in the reserve and were found mostly in the field (102 species, 1465 records), only 8 species of 25 records were obtained in moist chamber cultures. Of the 102 species inhabiting wood, 86 were found exclusively on this substrate. However, in terms of ACOR classes, only ten species, Physarum album (177 records), Ph. viride (72), Colloderma oculatum (66), Licea variabilis (61), Lycogala epidendrum (58), Stemonitopsis hyperopta (53 records), Licea pygmaea (47), Cribraria oregana (46), Stemonitis axifera (46), and Comatricha nigra (45) were abundant ( $>3 \%$ of all records) in the reserve, whereas 83 lignicolous species were rare ( $<0.5 \%$ of 1465 records).

Litter was the second most diverse substrate type, but only 17 of the 29 species occurred exclusively on this substrate type. Thirteen species found in litter were rare. Common species found only on different types of ground litter including mosses and dwarf shrubs were Diderma niveum (26 records), Physarum albescens (24 records), Lepidoderma chailletii (16 records, all three nivicolous), and Didymium squamulosum (15 records). Fuligo muscorum is the only myxomycete species that appears to be restricted to wet mossy ground litter in the reserve. We collected in the field only three specimens with mature fruit bodies (Figs. 3a, b), but other four records of plasmodia and immature sporocarps

Table 2. Statistical data for myxomycetes from the different substrate types. Abbreviations as in Table 1.

\begin{tabular}{llllll}
\hline & Bark & Litter & Wood & Dung & Total \\
\hline Records (fc/mc) & $0 / 37$ & $143 / 9$ & $1441 / 25$ & $0 / 21$ & $1584 / 92$ \\
\hline Species (fc/mc) & $0 / 10$ & $22 / 7$ & $101 / 8$ & $0 / 3$ & $117 / 21$ \\
\hline Chao1 \pm SD & $15 \pm 6$ & $52 \pm 16$ & $141 \pm 21$ & ND & $191 \pm 33$ \\
\hline Genera & 6 & 9 & 32 & 3 & 34 \\
\hline Species/Genera & 1.7 & 2 & 3.2 & 1 & 3.7 \\
\hline Shannon H' & 1.8 & 2.7 & 3.9 & ND & 4.1 \\
\hline Simpson's D & 4.7 & 10.5 & 28.7 & ND & 35.0 \\
\hline Number of mc & 90 & 50 & 30 & 40 & 210 \\
\hline$\%$ mc positive & 32 & 12 & 53 & 50 & 34 \\
\hline Species per mc (mean \pm SD) & $0.4 \pm 0.6$ & $0.2 \pm 0.6$ & $0.8 \pm 1.0$ & $0.5 \pm 0.5$ & $0.4 \pm 0.7$ \\
\hline
\end{tabular}

${ }^{1}$ Only cultures that yielded sporocarps were counted as positive. 
were damaged by animals (apparently lemmings).

Bark was the least diverse substrate type, with only 4 species recorded exclusively on this substrate. The most abundant corticolous species were Arcyria cinerea (36\% of 36 records), Perichaena chrysosperma (56\% of 43 records), Paradiacheopsis fimbriata (25\% of 12 records), and Physarum compressum (14\% of 15 records). While $51 \%$ of all bark moist chamber cultures were positive (displayed evidence of either plasmodia or sporocarps), only $32 \%$ yielded sporocarps (Table 2).

In the reserve, three species of myxomycetes have been recorded from weathered dung: Arcyria cinerea, Didymium difforme, and Physarum compressum. However, only the last species seems to be specialized on this substrate to some degree.

These relationships are as well reflected by the indicator species analysis (Fig 7): all substrates have several exclusive species with high indicator values. Wood shows the highest number of indicator species. In contrast, only a single species, Arcyria cinerea, has an indicator value for both wood and dung (Table S2, not shown in Fig. 7).

A dissimilarity comparison of the four studied forest types shows that the myxomycete assemblages of the Laplandskiy Reserve fall into three groups: one cluster formed by the two associations of mossy spruce forests (PICa and $\mathrm{PICb}$ ) and two further clusters for each dry spruce-pine (PIN) and subalpine birch forest (SB, Fig. 8).

Both myxomycete assemblages from mossy spruce forests show a high degree of overlap. Differences among assemblages in PICa and PICb are more the result of differences in the abundance of shared species than actual differences in species composition. Exceptions are Colloderma oculatum and Barbeyella minutissima. Both species seem to require constantly high air moisture, are limited to the spruce-peat moss forest (PICb) and are often associated with Physarum viride, Lepidoderma tigrinum, and Lamproderma columbinum (Schnittler et al. 2000, Stephenson et al. 2019). These species form a distinct ecological guild on large wet coarse coniferous woody debris covered by mosses and liverworts in boreal forests (Schnittler \& Novozhilov 1998).

Among nivicolous species, only Trichia sordida was found the first time for the Kola peninsula, other

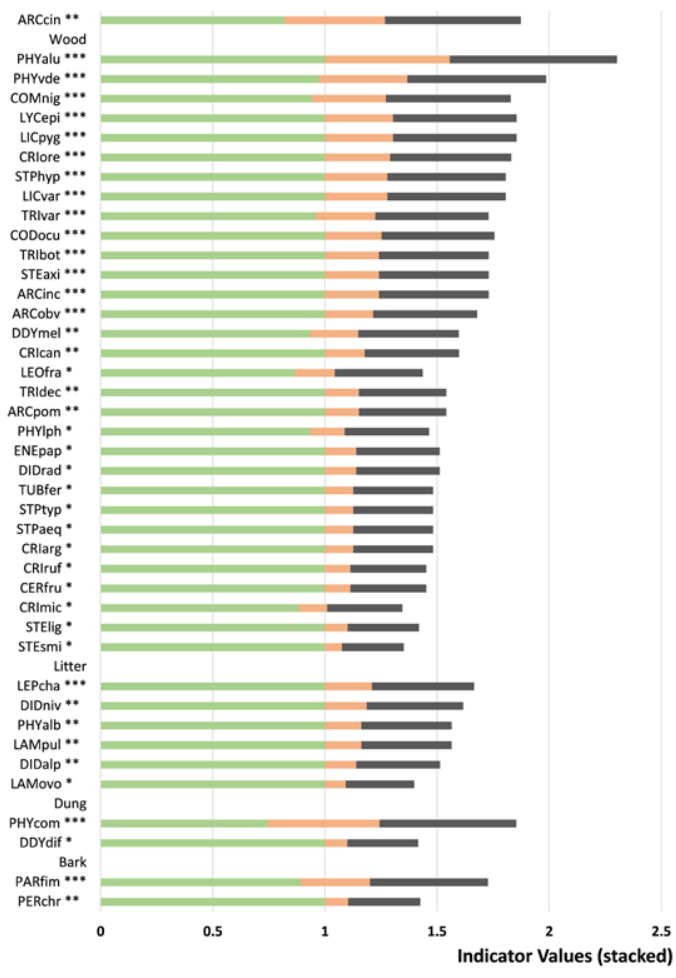

Fig. 7. Indicator species for the four main substrate types: decayed wood, forest floor litter, dung, and bark of living trees. For explanation of bars, significance values and abbreviations of myxomycete names see Fig. 6.

species of this guild were found in previous studies in the adjacent Khibiny Mts. (Erastova et al. 2017).

Summarizing, the Laplandskiy Reserve harbours a myxomycete biota with relatively high species richness and diversity ( 125 taxa, $\mathrm{H}^{\prime}=4.1, \mathrm{D}=$ 35.1 , reflecting the rather high diversity of vegetation in the reserve. Cribraria is the most diverse genus, all 18 species were found on decayed coniferous wood. Virtually all species known from temperate and boreal zones are fairly common in the reserve, like Physarum album, Ph. viride or Lycogala epidendrum. The proportions of species among myxomy- 
cete families revealed in the reserve are typical for myxomycete biota of the taiga forest (Novozhilov 1980, 1999, Schnittler \& Novozhilov 1996). If seen according to the traditional system, the four most common families recovered in the field are Cribrariaceae (19 species, 15\%, of all 125 taxa), Physaraceae (20 species, $16 \%$ ), Trichiaceae (28 species, $22 \%$,), and Stemonitidaceae (29 species, 23\%), making up for $76 \%$ of all taxa. These proportions differ between studied vegetation types. Both associations of pure spruce forest were relatively rich in Stemonitidaceae (PICa: 17 species, $20 \%$ of all 84 taxa; PICb:, 15 species, $21 \%$ of all 70 taxa), Trichiaceae (PICa: 20 species, 24\%; PICb: 16 species, 23\%), Cribrariaceae (PICa: 15 species, 18\%; PICb: 14 species, 20\%), and Physaraceae (PICa: 13 species, 15\%; PICb: 8 species, $11 \%$ ), whereas in the subalpine birch forest the proportion of members from the Cribrariaceae decreased ( 3 species, $10 \%$ of total 30 taxa). The taxonomic structure of myxomycete biota in the reserve corroborates results from other studies in boreal forests of Fennoscandia (Härkönen \& Varis 2013, Johannesen \& Vetlesen 2020). The main genera in the reserve are Cribraria (18 species), Physarum (15), Trichia (11), and Arcyria (10).

Interestingly, some genera common in the temperate zone, especially in deciduous forests, like Arcyodes, Brefeldia, Craterium, Diachea, Dictydiaethalium, Echinostelium, Mucilago, Prototrichia, and

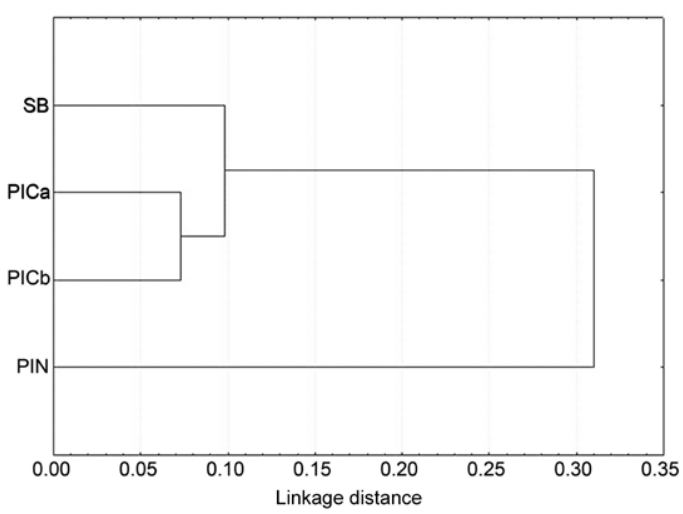

Fig. 8. Dendrogram of dissimilarity, based on the Chao-Soerensen similarity index (Table 3), of the relative occurrence of the species found in the forest types of the reserve (abbreviations of the forest types as explained in Material and Methods).

Reticularia, have not been revealed in the reserve. Further studies using the analysis of environmental DNA would show if they are present there as amoebal populations that rarely or never fruit or they are completely absent in the northern boreal forests of the reserve.

Table 3. Similarity of myxomycete assemblages between forest types (SB, PICa, PICb, and PIN) and substrate types (b, d, w, I - see text for explanations). The table shows the adjusted incidence-based Chao-Sorensen similarity index ( $C_{c s}$, upper right) and the number of species shared (lower left) for 125 myxomycete species. The last two rows indicate the mean figures of $\mathrm{C}_{\mathrm{cs}}$ for a study site (Mean) and its standard deviation (SD).

\begin{tabular}{l|lll|l|lllll}
\hline & \multicolumn{7}{|l|}{ Main forest types } & \multicolumn{5}{l}{ Substrates } \\
\hline & SB & PICa & PICb & PIN & & B & D & W & L \\
\hline SB & - & 0.18 & 0.12 & 0.06 & b & - & 0.63 & 0.09 & 0.03 \\
\hline PICa & 12 & - & 0.92 & 0.83 & d & 2 & - & 0.02 & 0.03 \\
\hline PICb & 9 & 58 & - & 0.90 & w & 5 & 1 & - & 0.14 \\
\hline PIN & 6 & 49 & 46 & - & I & 1 & 1 & 12 & - \\
\hline Mean & 0.12 & 0.65 & 0.64 & 0.60 & & 0.25 & 0.23 & 0.08 & 0.06 \\
\hline SD & 0.03 & 0.23 & 0.26 & 0.27 & & 0.33 & 0.35 & 0.06 & 0.07 \\
\hline
\end{tabular}




\section{Acknowledgements}

The authors are grateful to the administration of the Laplandskiy State Nature Biosphere Reserve, Natalia Berlina and Valeriy Barkan, for their assistance in the organization of the field work. We gratefully acknowledge the technical support (SEM) provided by Ludmila A. Kartzeva (The Core Facility Center "Cell and Molecular Technologies in Plant Science" at the Komarov Botanical Institute RAS, St. Petersburg, Russia) and help from Elizaveta Shchepina and Daria Erastova during the field work. This work was supported by Russian Foundation for Basic Research (project 18-04-01232 A), the state task of BIN RAS 'Biodiversity, ecology, structural and functional features of fungi and fungus-like protists' (AAAA-A19-119020890079-6) for O. Shchepin and Y. Novozhilov. The work with herbarium collections was supported by the grant of Moscow State University for leading scientific schools "Depository of the Living Systems" and the state task (AAAA-A16-116021660084-1) for V. Gmoshinskiy.

\section{References}

Ahti, T., Hämet-Ahti, L. \& Jalas, J. 1968: Vegetation zones and their sections in northwestern Europe. Annales Botanici Fennici 5: 169-211.

Barkan, V.Sh. Physical and geographical description of the territory of the Laplandsky Reserve.

On line at http://www.lapland-nature.info/ru/13.html (Consulted 16 September 2020, in Russian).

Barsukova, T.N., Gmoshinskii, V.I., Prokhorov, V.P. \& Dunaev, E.A. 2012: The slime moulds of S. N. Skadovsky Zvenigorod biological station of Moscow State University. Mikologia i Fitopatologia 46: 111-121. (in Russian).

Chao, A., Chazdon, R.L., Colwell, R.K. \& Shen, T.J. 2005: A new statistical approach for assessing similarity of species compostion with incidence and abundance data.

Ecology Letters 8: 148-159.

Chao, A., Chazdon, R.L., Colwell, R.K. \& Shen, T.J. 2006:

Abundance-based similarity indices and their estimation when there are unseen species in samples. Biometrics 62: 361-371.

Colwell, R.K. 2014: EstimateS 9.10 User's Guide.

Available from: http://viceroy.eeb.uconn.edu/EstimateS.
Czerepanov, S.K. 1995: Vascular Plants of Russia and Adjacent States (the former USSR). Russian edition. World and Family-95 Ltd.: St. Petersburg.

De Cáceres, M. \& Legendre, P. 2009: Associations between species and groups of sites: indices and statistical inference. Ecology 90: 3566-3574.

Eliasson, U. 2013: Coprophilous myxomycetes: Recent advances and future research directions Fungal Diversity 59: 85-90.

Eliasson, U.H. 1981: Patterns of occurence of myxomycetes in a spruce forest in South Sweden. Holarctic Ecology 4: 20-31.

Eliasson, U.H. \& Lundqvist, N. 1979: Fimicolous myxomycetes. Botaniska Notiser 132: 551-568.

Elvebakk, A., Gjaerum, H.B. \& Sivertsen, S. 1996: Part 4. Fungi Il. Myxomycota, Oomycota, Chytridiomycota, Zygomycota, Ascomycota, Deuteromycota, Basidiomycota: Uredinales and Ustilaginales. In: Elvebakk, A. \& Prestrud, P. (eds.). A catalogue of Svalbard plants, fungi, algae and cyanobacteria. Skrifter N 198, 207-259. Norsk Polarinstitutt, Oslo.

Erastova, D.A. \& Novozhilov, Y.K. 2015: Nivicolous myxomycetes of the lowland landscapes of the Northwest of Russia. Mikologia i Fitopatologia 49: 7-16.

Erastova, D.A., Novozhilov, Y.K. \& Schnittler, M. 2017: Nivicolous myxomycetes of the Khibiny Mountains, Kola Peninsula, Russia.. Nova Hedwigia 104: 85-110.

Farr, M.L. 1962: Arcyria cinerea and A. pomiformis revised. Mycologia 54: 516-519.

Farr, M.L. 1976: Flora Neotropica Monograph No. 16 Myxomycetes. New York Botanical Garden: New York.

Gmoshinskiy, V.I. \& Matveev, A.V. 2016: Season dynamics of sporulation of myxomycetes in Moscow city and Moscow region. Mikologia i Fitopatologia 50: 139-147.

Gmoshinskiy, V.I. \& Matveev, A.V. 2019: First data on myxomycetes of Polistovsky nature reserve (Pskov region). Novosti Systematiki Nizshikh Rasteniy. 53: 279-290. (in Russian).

Gotelli, N.J. \& Colwell, R.K. 2011: Chapter IV. Estimating species richness. In: Magurran, A.E. \& McGill, B.J. (eds.). Biological Diversity Frontiers in Measurement and Assessment, 39-54. Oxford University Press Inc., New York. 
Hämet-Ahti, L. 1963: Zonation of the mountain birch forests in northernmost Fennoscandia. Annales Botanici Societatis Zoologicæ Botanicæ Fennicæ 'Vanamo' 34: 1-127.

Härkönen, M. 1977a: Comatricha nannengae,a new species of Myxomycetes. Karstenia 17: 87-89.

Härkönen, M. 1977b: Corticolous myxomycetes in three different habitats in southern Finland. Karstenia 17: 19-32.

Härkönen, M. 1979: A check-list of Finnish myxomycetes. Karstenia 19: 8-18.

Härkönen, M., Ukkola, T. \& Pekkala, K. 1999: Additions and amendments to the myxomycetes in Finland.

Karstenia 39: 49-57.

Härkönen, M. \& Varis, E. 2013: Suomen Limasienet [The Myxomycetes of Finland]. 240. Finnish Museum of Natural History, Helsinki.

Hintikka, T.J. 1919: Revision des myxogastres de Finlande. Acta societatis pro fauna et flora Fennica. 46: 1-43.

Hogan, M.C. 2012: Scandinavian and Russian taiga. Encyclopedia of Earth, National Council for Science an the Environment. Washington DC. On line at http://editors.eol. org/eoearth/wiki/Scandinavian_and_Russian_taiga (Consulted 16 September 2020).

Johannesen, E.W. 1984a: New and interesting Myxomycetes from Norway. Nordic Journal of Botany 4: 513-520.

Johannesen, E.W. 1984b: A new species of Trichia (Myxomycetes) from Norway. Mycotaxon 20: 81-84.

Johannesen, E.W. \& Vetlesen, P. 2020: New and rare myxomycetes (Mycetozoa, Myxogastria) in Norway, including a complete checklist of Norwegian myxomycete species. Agarica 40: 1-138.

Karsten, P.A. 1882: Enumeratio Fungorum et Myxomycetum in Lapponia orientali aestate 1861 lectorum (impr. 1866). Notiser ur Sällskapets pro Fauna et Flora Fennica förhandlingar. 8: 193-224.

Koroleva, N.E. 1999: Snow-bed plant communities of the Lapland Nature Reserve (Murmansk region, Russia). Chemosphere - Global Change Science 1: 429-437.

Kottek, M., Grieser, J., Beck, C., Rudolf, B. \& Rubel, F. 2006: World Map of the Köppen-Geiger climate classification updated. Meteorologische Zeitschrift 15: 259-263.
Lado, C. 2005-2020: An on-line nomenclatural information system of Eumycetozoa. On line at http://www.nomen.eumycetozoa.com (consulted 8 June 2020).

Leontyev, D.V., Schnittler, M. \& Stephenson, S.L. 2015: A critical revision of the Tubifera ferruginosa-complex. Mycologia 107: 959-985.

Leontyev, D.V., Schnittler, M., Stephenson, S.L. \& Novozhilov, Y.K. 2019: Systematic revision of the Tubifera casparyi-T. dictyoderma complex: Resurrection of the genus Siphoptychium and introduction of the new genus Thecotubifera.

Mycologia 111: 981-997.

Lukina, N.V. \& Chernen'kova, T.V. 2008: Pollution-induced successions in forests of the Kola Peninsula. Russian Journal of Ecology 39: 310-317.

Magurran, A.E. 2004: Measuring biological diversity. Blackwell Publishing: Malden, Massachusetts.

Marshall, G.J., Vignols, R.M. \& Rees, W.G. 2016: Climate Change in the Kola Peninsula, Arctic Russia, during the Last 50 Years from Meteorological Observations. Journal of Climate 29: 6823-6840.

Martin, G.W. \& Alexopoulos, C.J. 1969: The Myxomycetes. Univ. of lowa Press: lowa City.

McCune, B. \& Mefford, M.J. 2006: PC-ORD. Multivariate Analysis of Ecological Data, Version 4.0. MjM Software Design Gleneden Beach, Oregon.

Nannenga-Bremekamp, N.E. \& Yamamoto, Y. 1990: Additions to the Myxomycetes of Japan IV. Proceedings of the Koninklijke Nederlandse Akademie van Wetenschappen 93: 265-280.

Neshataev, V.Y. \& Neshataeva, V.Y. 2002: Syntaxonomic diversity of pine forests in the Lapland Nature Reserve. Botanicheskiy Zhurnal 87: 99-106. (in Russian).

Novozhilov, Y.K.. 1980: Myxomycetes of the Central Forest State Reserve and the Leningrad Region. Mikologia i Fitopatologia 14: 198-201 (in Russian).

Novozhilov, Y.K. 1999: Myxomycetes of the Leningrad Region. In: Balashova, N.V. \& Zavarzin, A.A. (eds.). In: Biodiversity of the Leningrad Region, Proceedings of Saint Petersburg Society of Naturalists. Ser. 6. Saint Petersburg. 197-204 (in Russian).

Novozhilov, Y.K., \& Lebedev, A.N. 2006: An annotated list of lignicolous myxomycetes of the Tver' oblast' (Russia). Mikologia i Fitopatologia 40: 236-245. (in Russian). 
Novozhilov, Y.K. \& Schnittler, M. 1997: Nivicole myxomycetes of the Khibine mountains (Kola peninsula). Nordic Journal of Botany 16: 549-561.

Novozhilov, Y.K., Schnittler, M., Erastova, D.A., \& Shchepin, O.N. 2017: Myxomycetes of the Sikhote-Alin State Nature Biosphere Reserve (Far East, Russia). Nova Hedwigia 104: 183-209.

Novozhilov, Y.K., Schnittler, M. \& Stephenson, S.L. 1998: Analysis of myxomycete diversity of Russian subarctic and arctic areas. Mikologia i Fitopatologia 32: 27-33.

Ogureeva, G.N. 2010: Ecological-geographical base for biodiversity of boreal forests in Russia. In: Talbot, S., Charron, T. \& Barry, T. (eds.): Proceedings of the Fifth International Workshop: Conservation of Arctic Flora and Fauna (CAFF) Flora Group. Circumboreal Vegetation Mapping (CBVM) Workshop, Helsinki, Finland, November 3-6th, 2008. CAFF

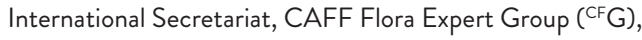
CAFF Technical Report No. 21.: 42-51. CAFF International Secretariat, CAFF Flora Expert Group ( $\left.{ }^{\mathrm{CF}} \mathrm{G}\right)$, CAFF Technical Report No. 21., Helsinki.

Poulain, M., Meyer, M. \& Bozonnet, J. 2011: Les Myxomycètes. Federation mycologique et botanique Dauphine-Savoie: Sevrier.

Ronikier, A. \& Ronikier, M. 2009: How 'alpine' are nivicolous myxomycetes? A worldwide assessment of altitudinal distribution. Mycologia 101: 1-16.

Schnittler, M. \& Novozhilov, Y.K. 1996: The myxomycetes of boreal woodlands in Russian northern Karelia: a preliminary report. Karstenia 36: 19-40.

Schnittler, M. \& Novozhilov, Y.K. 1998: Late-autumn myxomycetes of the northern Ammergauer Alps. Nova Hedwigia 66: 205-222.

Schnittler, M., Stephenson, S.L. \& Novozhilov, Y.K. 2000 : Ecology and world distribution of Barbeyella minutissima (Myxomycetes). Mycological Research 104: 1518-1523.

Shchepin, O.N., Schnittler, M., Erastova, D.A., Prikhodko, I.S., Borg Dahl, M. et al. 2019: Community of dark-spored myxomycetes in ground litter and soil of taiga forest (Nizhne-Svirskiy Reserve, Russia) revealed by DNA metabarcoding. Fungal Ecology 39: 80-93.

Stephenson, S.L., Kalyanasundaram, I. \& Lakhanpal, T.N. 1993: A comparative biogeographical study of myxomycetes in the mid-Appalachians of eastern North America and two regions of India. Journal of Biogeography 20: 645-657.
Stephenson, S.L., Novozhilov, Y.K., Almadrones-Reyes, K.J., Dagamac, N.H.A. \& Schnittler, M. 2019: New records of Barbeyella minutissima (Myxomycetes, Echinosteliales) with an updated distribution map. Nova Hedwigia 109: 177-186.

Stephenson, S.L., Novozhilov, Y.K. \& Schnittler, M. 2000: Distribution and ecology of myxomycetes in high-latitude regions of the northern hemisphere. Journal of Biogeography 27: 741-754.

Vlasenko, A.V., Novozhilov, Y.K., Prikhodko, I.S., Botyakov, V.N. \& Vlasenko, V.A. 2020: A new species of Stemonitis pseudoflavogenita from Russia, and the first record of Stemonitis capillitionodosa in Eurasia. Phytotaxa 447: 137-145.

Wehberg, J., Thannheiser, D. \& Meier, K.D. 2005: Vegetation of the Mountain Birch Forest in Northern Fennoscandia. In: Caldwell, M.M. et al. (edS.) Plant Ecology, Herbivory, and Human Impact in Nordic Mountain Birch Forests. Ecological Studies (Analysis and Synthesis), 35-52. Springer, Berlin, Heidelberg.

Supplementary material (available from the authors upon request) 